\title{
Ozonolysis of $\alpha$-phellandrene - Part 2: Compositional analysis of secondary organic aerosol highlights the role of stabilised Criegee intermediates
}

\author{
Felix A. Mackenzie-Rae ${ }^{1}$, Helen J. Wallis ${ }^{2}$, Andrew R. Rickard ${ }^{2,3}$, Kelly L. Pereira ${ }^{2}$, Sandra M. Saunders ${ }^{1}$, \\ Xinming Wang ${ }^{4,5}$, and Jacqueline F. Hamilton ${ }^{2}$ \\ ${ }^{1}$ School of Molecular Sciences, The University of Western Australia, Crawley WA 6009, Australia \\ ${ }^{2}$ Wolfson Atmospheric Chemistry Laboratories, Department of Chemistry, University of York, York, YO10 5DD, UK \\ ${ }^{3}$ National Centre for Atmospheric Science, University of York, York, YO10 5DD, UK \\ ${ }^{4}$ State Key Laboratory of Organic Geochemistry and Guangdong Key Laboratory of Environmental Protection and Resources \\ Utilization, Guangzhou Institute of Geochemistry, Chinese Academy of Sciences, Guangzhou 510640, China \\ ${ }^{5}$ Center for Excellence in Regional Atmospheric Environment, Institute of Urban Environment, Chinese Academy \\ of Sciences, Xiamen 361021, China
}

Correspondence: Jacqueline F. Hamilton (jacqui.hamilton@york.ac.uk)

Received: 12 July 2017 - Discussion started: 14 August 2017

Revised: 23 February 2018 - Accepted: 23 February 2018 - Published: 6 April 2018

\begin{abstract}
The molecular composition of the water-soluble fraction of secondary organic aerosol (SOA) generated from the ozonolysis of $\alpha$-phellandrene is investigated for the first time using high-pressure liquid chromatography coupled to high-resolution quadrupole-Orbitrap tandem mass spectrometry. In total, 21 prominent products or isomeric product groups were identified using both positive and negative ionisation modes, with potential formation mechanisms discussed. The aerosol was found to be composed primarily of polyfunctional first- and second-generation species containing one or more carbonyl, acid, alcohol and hydroperoxide functionalities, with the products significantly more complex than those proposed from basic gas-phase chemistry in the companion paper (Mackenzie-Rae et al., 2017). Mass spectra show a large number of dimeric products are also formed. Both direct scavenging evidence using formic acid and indirect evidence from double bond equivalency factors suggest the dominant oligomerisation mechanism is the bimolecular reaction of stabilised Criegee intermediates (SCIs) with non-radical ozonolysis products. Saturation vapour concentration estimates suggest monomeric species cannot explain the rapid nucleation burst of fresh aerosol observed in chamber experiments; hence, dimeric species are believed to be responsible for new particle formation, with detected first- and second-generation products driving further particle growth
\end{abstract}

in the system. Ultimately, identification of the major constituents and formation pathways of $\alpha$-phellandrene SOA leads to a greater understanding of the atmospheric processes and implications of monoterpene emissions and SCIs, especially around eucalypt forests where $\alpha$-phellandrene is primarily emitted.

\section{Introduction}

Aerosols are abundant in the atmosphere, playing an important role in the climate system by scattering and absorbing radiation, influencing cloud formation and participating in heterogeneous chemical processes (Carslaw et al., 2010; Hallquist et al., 2009; IPCC, 2013). Furthermore, it is well established that atmospheric aerosols have an important impact on local air quality and human health, with exposure associated with detrimental effects on the respiratory and cardiovascular systems (Brook et al., 2010; Pope and Dockery, 2006). Nevertheless, there remains a large amount of uncertainty regarding the true impact of atmospheric aerosols on climate and health, driven by a general lack of understanding in sources, formation mechanisms, composition and properties (Hallquist et al., 2009). 
A common feature of atmospheric aerosol is the presence of condensed secondary organic material, formed as a result of oxidation of volatile organic compounds (VOCs) into less volatile, condensable species (Jimenez et al., 2009; Kanakidou et al., 2005). With significant biogenic emissions (Guenther et al., 1995, 2012), high chemical reactivity (Atkinson and Arey, 2003) and large secondary organic aerosol (SOA) formation yields (Griffin et al., 1999; Hoffmann et al., 1997), monoterpenes are important contributors to organic aerosol globally, with their ozonolysis a dominant pathway for SOA formation and growth (Jokinen et al., 2015; Ortega et al., 2012; D. F. Zhao et al., 2015). Despite this, the literature has predominantly focused on a small number of the more commonly emitted monoterpenes (e.g. $\alpha$-pinene, $\beta$-pinene, limonene), which, whilst important on the global scale, fails to consider the impact that other monoterpenes can have on local environments. For instance, $\alpha$-phellandrene is one of the most reactive monoterpenes (Atkinson and Arey, 2003), yet relatively little is known about its tropospheric degradation and subsequent aerosol forming characteristics. $\alpha$-Phellandrene has been measured in field studies in Brazil (Kesselmeier et al., 2000) and Japan (Ramasamy et al., 2016), although it has been noted that ambient detection is made difficult by its extremely high reactivity (Geron et al., 2000; Saxton et al., 2007). $\alpha$-Phellandrene has been identified in high abundance in the extracts of numerous species of eucalypts (Brophy and Southwell, 2002; Li et al., 1995; Maghsoodlou et al., 2015; Pavlova et al., 2015), with monoterpene emission rates known to increase linearly with concentration in plant tissue (Fuentes et al., 2000). Indeed, Maleknia et al. (2009) and He et al. (2000) have both identified $\alpha$-phellandrene in emissions from various eucalypt species in the laboratory, with it likely then that $\alpha$-phellandrene is a non-negligible contributor to the large monoterpene emissions reported from eucalypt forests (Emmerson et al., 2016). Native to Australasia, the remarkable adaptability, rapid growth rates and high-quality wood of eucalypts have led to plantation forestry in more than 100 countries spanning six continents ( $>20$ million ha), making eucalypts the most widely planted hardwood forest trees in the world (Myburg et al., 2014).

In the companion paper (Part 1, Mackenzie-Rae et al., 2017), it was found that $\alpha$-phellandrene yields a large amount of self-nucleated SOA upon reaction with ozone, concluding that the ozonolysis of $\alpha$-phellandrene is likely an important contributor to the intense and frequent nocturnal nucleation events observed in eucalypt forests (Lee et al., 2008; Ortega et al., 2012; Suni et al., 2008). However, gas-phase species postulated in the companion paper could not explain the properties of the SOA observed. Nucleation was inhibited in experiments that introduced a Criegee intermediate (CI) scavenger into the system, thereby identifying CIs as important precursors to nucleating compounds, whilst temporal growth profiles showed both first- and second-generation products to be major contributors to the SOA mass. This find- ing is consistent with recent literature that is building around stabilised Criegee intermediates (SCIs) as important precursors to SOA nucleation and growth, although the mechanism describing how SCIs form condensable products is still open to debate (Bateman et al., 2009; Bonn et al., 2002; Kristensen et al., 2016; Sadezky et al., 2006, 2008; Sakamoto et al., 2013; Ahmad et al., 2017).

This paper extends the current discussion by analysing filter samples collected during the $\alpha$-phellandrene ozonolysis chamber experiments (as described in Mackenzie-Rae et al., 2017). Samples were analysed using a combination of liquid chromatography with soft-ionisation electrospray mass spectrometry. This technique is sensitive towards polar organic molecules containing basic or acidic (ionisable) functional groups, with the technique having previous success in identifying compounds within SOA generated from monoterpene ozonolysis (e.g. Bateman et al., 2009; Camredon et al., 2010; Gao et al., 2004; Walser et al., 2008; Warnke et al., 2006; Witkowski and Gierczak, 2017; Zhang et al., 2015). The objective of this study is therefore to identify SOA constituents from the gas-phase ozonolysis of $\alpha$-phellandrene and their associated formation mechanism for the first time.

\section{Method}

\subsection{Chamber experiments}

SOA was generated and sampled during 11 dark $\alpha$ phellandrene ozonolysis experiments using the indoor smog chamber facility at the Guangzhou Institute of Geochemistry, Chinese Academy of Sciences (GIG-CAS, Wang et al., 2014). The complete experimental design and details are provided in the companion paper (Mackenzie-Rae et al., 2017). Briefly, $\alpha$-phellandrene (10175 ppb; Sigma-Aldrich Chemical Company, Inc., USA) and ozone $(56-500 \mathrm{ppb})$ were mixed in a background matrix of purified air. All experiments were conducted under low humidity conditions (relative humidity $(\mathrm{RH}) \leq$ $5 \%)$, room temperature $(\sim 298 \mathrm{~K})$ and ambient pressure ( $\sim 760$ Torr). All but two experiments (9 and 11) had anhydrous cyclohexane (Sigma-Aldrich, 99.5\%) added in sufficient quantity as an $\mathrm{OH}$ radical scavenger, with one of the non-OH-scavenged experiments having $385 \mathrm{ppb}$ of $\mathrm{NO}_{2}$ added (experiment 11). Two experiments (6 and 7) had $800 \pm 80 \mathrm{ppb}$ formic acid (J\&K Scientific Ltd., $98 \%$ ) added as a SCI scavenger (Bonn et al., 2002; Winterhalter et al., 2009). Particle number size distributions were measured by a scanning mobility particle sizer (SMPS; TSI Inc., USA) (Wang and Flagan, 1990), with particle mass concentrations calculated to range from 21 to $660 \mu \mathrm{g} \mathrm{m}^{-3}$, whilst particle chemical composition was measured in real time by a highresolution time-of-flight aerosol mass spectrometer (AMS; Aerodyne Research Inc., USA) (DeCarlo et al., 2006; Jayne et al., 2000). Aerosol samples were collected on pre-fired 
Whatman quartz microfiber filters $(47 \mathrm{~mm})$ by pumping air through the filter at $16-25 \mathrm{slpm}$, for a minimum of $2 \mathrm{~h}$ after chamber conditions had reached a steady state. Filter samples were then wrapped in foil and dried in a desiccator for $24 \mathrm{~h}$, before being stored at $4{ }^{\circ} \mathrm{C}$ prior to analysis. Specific starting conditions and information pertaining to SOA collection for each of the 11 experiments are presented in Table 1.

\subsection{Sample preparation and analysis}

Filter samples were extracted by sonication using liquid chromatography - mass spectrometry (LC-MS) Optima grade water (Fisher Scientific) as the solvent. Previous studies have shown that water can extract the majority of the SOA mass formed in chamber experiments, with a very low background organic signature (Hamilton et al., 2008). The sample solution was then filtered through a $0.45 \mu \mathrm{m}$ pore syringe (Millex-HA), with a further $1 \mathrm{~mL}$ of water added to the dry filter paper residue for a second extraction following the same method. Combined extraction samples were then evaporated to dryness using a V10 vacuum solvent evaporator (Biotage, $36{ }^{\circ} \mathrm{C}, 8 \mathrm{mbar}$ ). Lastly, the residue was resuspended in $500 \mu \mathrm{L}$ of $50: 50$ methanol-water (Optima LCMS grade, Fisher Scientific) solution, with dissolution aided by the Biotage evaporator (4000 rpm). Sample exposure to ambient light was minimised throughout the extraction process. Preconditioned filters, prepared by heating blank filter papers (Whatman quartz microfiber filters, $47 \mathrm{~mm}$ ) in a furnace at $550^{\circ} \mathrm{C}$ for $5 \mathrm{~h}$, were analysed as a procedural blank following the same method.

Samples were analysed using reversed-phase highperformance liquid chromatography (HPLC) (Agilent 1100 series, Berkshire, UK) coupled to a Q Exactive Hybrid quadrupole-Orbitrap Mass Spectrometer (Thermo Scientific). Samples $(30 \mu \mathrm{L})$ were injected using an autosampler and separated using a Pinnacle DB $\mathrm{C}_{18}$ column with $5 \mu \mathrm{m}$ particle size (Thames Restek, UK). The starting mobile phase consisted of a gradient from $85 \%$ water, with $0.1 \%$ formic acid (Sigma-Aldrich), and $15 \%$ methanol (LC-MS Optima grade, Fisher Scientific), to $10 \%$ of the water-formic acid solution and $90 \%$ methanol over $13 \mathrm{~min}$, before holding this ratio for a further minute. Electrospray ionisation (ESI, $35 \mathrm{eV}$ ) was used in both positive and negative modes with full mass spectra scans acquired between $\mathrm{m} / \mathrm{z} 50$ and 750 with a resolution of 70000 at $m / z 200$. Ions were additionally fragmented using high-energy collisional dissociation to yield tandem mass spectrometry (MS/MS) for structural identification. The MS was mass calibrated using ESI positive and negative ion calibration solutions every day (Pierce, Thermo Scientific). Data analysis was conducted using Xcalibur mass spectrometry software, assuming the only atoms present were ${ }^{12} \mathrm{C},{ }^{13} \mathrm{C},{ }^{1} \mathrm{H}$ and ${ }^{16} \mathrm{O}$ in the negative ionisation mode in addition to ${ }^{23} \mathrm{Na}$ in the positive ionisation mode. Analysis of the preconditioned filters showed only baseline noise, confirming that the peaks in the chromatograms were not due to artefacts of sample preparation. No evidence of methylation, which has been reported in other works using methanol as the extracting solvent (Walser et al., 2008), was observed in any of the tandem mass spectra.

\section{Results and discussion}

\subsection{Product identification}

Negative mode analysis leads to formation of deprotonated ions $\left([\mathrm{R}-\mathrm{H}]^{-}\right)$; hence, molecules containing functional groups that readily lose a proton, such as carboxylic acids, are frequently observed in this mode. Meanwhile, in positive mode analysis, ions are produced by protonation or cationisation with sodium ions $\left([\mathrm{R}+\mathrm{Na}]^{+}\right)$, which are present in the glassware used and, in the case of oxygenated functionalities, can improve detection and sensitivity (Hamilton et al., 2008). Hence, groups that more readily accept a positive charge, such as carbonyls, are often observed in positive mode analysis, which are expected to be dominated by sodium ion adducts (Camredon et al., 2010). Because a large fraction of first- and second-generation products of $\alpha$-phellandrene ozonolysis contain at least one functional group that is capable of ionisation (Mackenzie-Rae et al., 2016, 2017), it is reasonable to assume that a high proportion of water-soluble SOA components will be observed. Due to a lack of calibration standards, only a qualitative comparison of SOA composition can be achieved. Ionisation efficiency of individual molecules can vary significantly in ESI and so the largest peak may not represent the most abundant species.

Accurate mass measurements were used to assign molecular formulae to SOA components with mass accuracy of less than 2 ppm. $\alpha$-Phellandrene has an interesting structure for understanding SOA formation mechanisms. It has two double bonds within the ring; reaction with ozone at the first bond opens the ring, while the second ozone addition causes fragmentation. Thus, the dominant SOA components from the first oxidation will likely have 10 carbons. Those produced from the second will have seven or three carbons, with the latter unlikely to form significant SOA mass. The following sections will focus initially on the composition of SOA formed during standard $\alpha$-phellandrene ozonolysis experiments. The final section will focus on the impact of adding a SCI scavenger during the experiments.

\subsubsection{Negative mode}

The chromatograms produced using negative mode ionisation were reasonably consistent across the experimental suite, showing the same characteristic major peaks irrespective of experimental conditions. Two example chromatograms, from experiments with and without formic acid, are shown in Fig. 1 with major peaks detected across all experiments labelled in retention time order. Using high mass accuracy tandem mass spectra, the structure of 12 major 
Table 1. Experimental conditions (from the companion paper) and SOA collection information for chamber experiments.

\begin{tabular}{lrrrrlrr}
\hline Exp no. $^{\mathrm{a}}$ & $\begin{array}{r}\text { Temp. } \\
(\mathrm{K})\end{array}$ & $\begin{array}{r}\mathrm{RH} \\
(\%)\end{array}$ & $\begin{array}{r}\mathrm{VOC}^{\mathrm{b}} \\
(\mathrm{ppb})\end{array}$ & $\begin{array}{r}\mathrm{O}_{3} \\
(\mathrm{ppb})\end{array}$ & Additives & $\begin{array}{r}\text { Total SOA mass } \\
\left(\mu \mathrm{m}^{-3}\right)^{\mathrm{c}}\end{array}$ & $\begin{array}{r}\text { SOA mass collected } \\
\left( \pm 0.01, \mathrm{mg}^{2}\right.\end{array}$ \\
\hline 1 & $297.1 \pm 0.4$ & $2.5 \pm 0.6$ & $19 \pm 7$ & $>259$ & Cyclohexane & $86 \pm 9$ & $21 \pm 2$ \\
2 & $297.5 \pm 0.5$ & $2.1 \pm 0.7$ & $10 \pm 4$ & $>86$ & Cyclohexane & $121 \pm 13$ & $312 \pm 33$ \\
3 & $297.2 \pm 0.2$ & $2.3 \pm 0.6$ & $21 \pm 8$ & $>83$ & Cyclohexane & $178 \pm 19$ & 0.16 \\
4 & $297.4 \pm 0.5$ & $2.2 \pm 0.9$ & $32 \pm 13$ & $>193$ & Cyclohexane & $52 \pm 6$ & 0.21 \\
5 & $297.6 \pm 0.7$ & $1.8 \pm 0.4$ & $29 \pm 11$ & $>114$ & Cyclohexane & $28 \pm 3$ & 0.15 \\
6 & $298.0 \pm 0.3$ & $1.6 \pm 0.1$ & $16 \pm 6$ & $>470$ & Cyclohexane, formic acid & $341 \pm 36$ & 0.12 \\
7 & $298.0 \pm 0.1$ & $1.9 \pm 0.2$ & $19 \pm 8$ & $>499$ & Cyclohexane, formic acid & $658 \pm 70$ & 0.10 \\
8 & $298.7 \pm 0.6$ & $5.2 \pm 0.2$ & $61 \pm 24$ & $>56$ & Cyclohexane & $505 \pm 53$ & 0.50 \\
9 & $298.5 \pm 0.4$ & $4.9 \pm 0.4$ & $67 \pm 27$ & $>101$ & - & & 0.70 \\
10 & $298.2 \pm 0.5$ & $4.8 \pm 0.3$ & $175 \pm 69$ & $>174$ & Cyclohexane & 0.74 \\
\hline
\end{tabular}

${ }^{\mathrm{a}}$ Refer to Mackenzie-Rae et al. (2017). ${ }^{\mathrm{b}} \alpha$-Phellandrene. ${ }^{\mathrm{c}}$ Wall loss corrected.

compounds has been identified (Table 2), with structural elucidation consistent with postulated degradation mechanisms (Mackenzie-Rae et al., 2016, 2017). Labelled tandem mass spectra are provided in the Supplement (Sect. S1). All identified species contain carboxylic acid functionality, with a characteristic loss of $44 \mathrm{Da}$ from the parent signal observed in all tandem mass spectra, showing a clear bias in negative mode ESI towards compounds containing acid functionality.

The peak at retention time $7.06 \mathrm{~min}(\mathrm{~N} 8)$ is the major peak in all negative mode chromatograms, with $[\mathrm{M}-\mathrm{H}]^{-}=$ $m / z 159$ and a neutral formula of $\mathrm{C}_{7} \mathrm{H}_{12} \mathrm{O}_{4}$. A molecular formula with seven carbon atoms indicates a second-generation product. In addition to a loss of $44 \mathrm{Da}$, the tandem mass spectrum is also characterised by a loss of $18 \mathrm{Da}$, suggesting the presence of further functionalisation, in this case likely an alcohol group. Two plausible isomeric species have been suggested based on this information (Table 2). As shown in Fig. 2, for one isomer, acid formation occurs through stabilisation of the CI from one ozone addition, whilst the CI from the other addition decomposes via the hydroperoxide channel, whereby the excited CI isomerises through a H-shift to form a vinylhydroperoxide which subsequently decomposes into a vinoxy radical and a hydroxyl radical (Johnson and Marston, 2008; Niki et al., 1987). Molecular oxygen then adds to the vinoxy radical which ultimately yields an alcohol group. Both of these are major reaction pathways and can explain the high abundance of compound N8 in $\alpha$-phellandrene SOA. Theoretical results show the energy barrier for accessing the hydroperoxide channel from the primary $\mathrm{CI}$ generated from the more substituted double bond is around $20 \mathrm{~kJ} \mathrm{~mol}^{-1}$ lower in energy than the respective barrier for accessing the hydroperoxide channel from the relevant CI from the less substituted double bond (Mackenzie-Rae et al., 2016). Based on this information, the secondary-alcohol isomer (formation mechanism shown in Fig. 2) is favoured as compound N8.
Alternatively, if the peroxy radical formed during the hydroperoxide channel were to form a ketone rather than an alcohol, then compound N1 would be formed, as shown in Fig. 2. This product was identified at retention time $3.81 \mathrm{~min}$, with a $[\mathrm{M}-\mathrm{H}]^{-}=m / z .157$ and a neutral formula of $\mathrm{C}_{7} \mathrm{H}_{10} \mathrm{O}_{4}$. The mechanism yielding adjacent aldehyde and ketone functional groups is only accessible for the CIs formed from ozonolysis of the more substituted double bond in $\alpha$-phellandrene, with the other CIs unable to form a ketone without fragmenting, due to the $\alpha$-carbons being tertiary. This comparative lack in mechanistic flexibility, along with a higher vapour pressure, may explain why compound $\mathrm{N} 1$ is relatively minor compared to N8.

The prominent peaks at retention times 5.01 (N4) and $5.39 \mathrm{~min}(\mathrm{~N} 5)$ are due to isomeric molecules with $[\mathrm{M}-\mathrm{H}]^{-}=m / z 175$ and a neutral formula of $\mathrm{C}_{7} \mathrm{H}_{12} \mathrm{O}_{5}$. These two peaks are observed in all samples analysed with varying relative intensities. Tandem mass spectra for these two species are similar, with a number of common ion peaks, suggesting similar structures containing acid and hydroxyl functionalities, differing only by positioning of these functional groups within the molecule. Nonetheless, a small number of minor differences in MS/MS fragmentation enables structural elucidation. N4 is formed through initial ozonolysis of the least substituted double bond, with the second addition of ozone participating in the hydroperoxide channel on the fragment $\mathrm{C}_{7}$ backbone, before undergoing a number of isomerisations, as shown in Fig. 3. Meanwhile, N5 is formed from ozone addition occurring in the reverse order. In general, the peak area of N4 is around twice as large as that for N5. The exact structures were confirmed by comparison to reference spectra available in the online mzcloud database (https://www.mzcloud.org/), with similarities of 94 and $96 \%$ for N4 and N5, respectively (see Sect. S1 in the Supplement). Given vapour pressures are likely to be very similar (Table 2), this observation suggests that either initial 

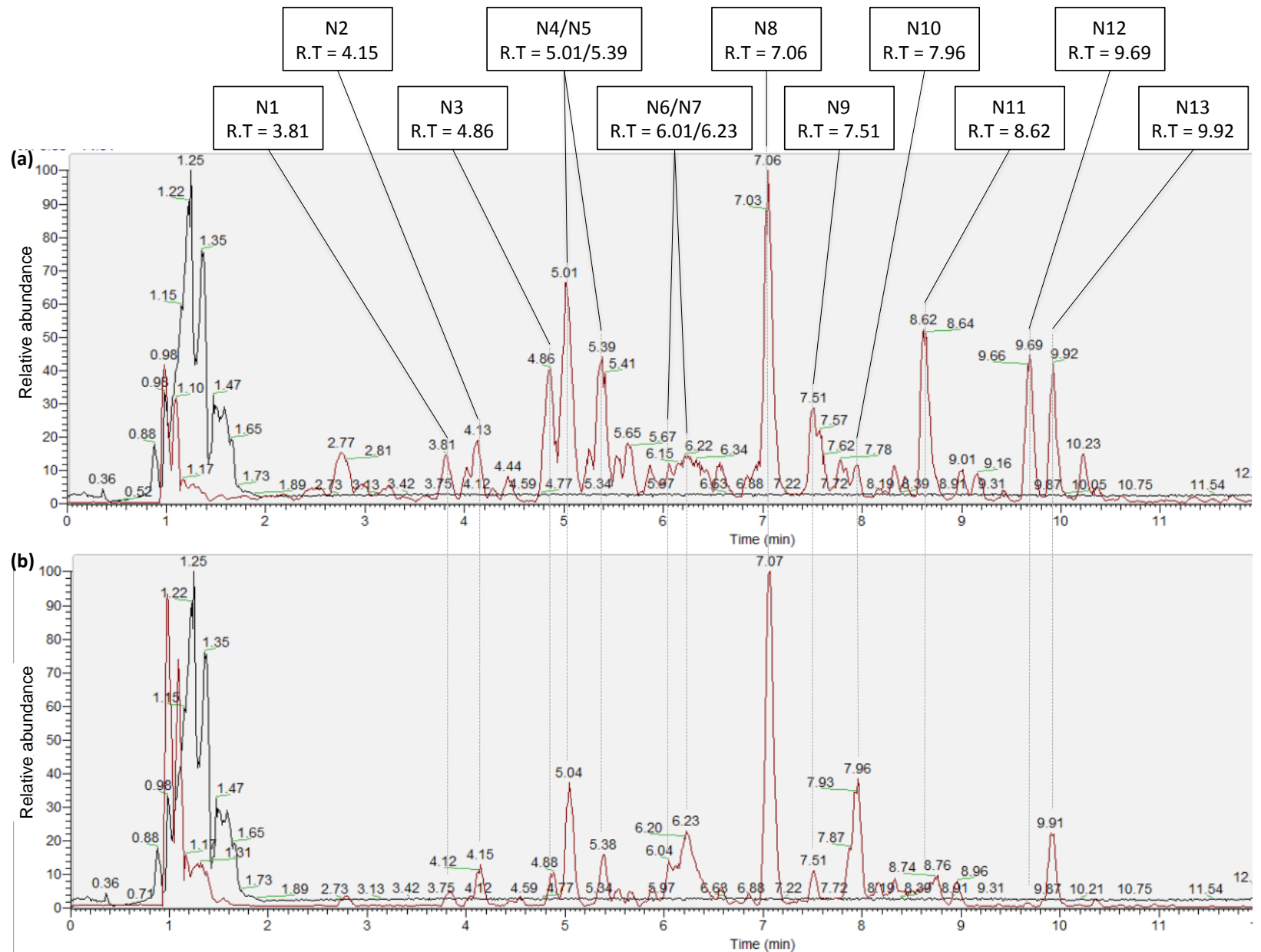

Figure 1. Negative ionisation mode chromatogram of SOA generated from the ozonolysis of $\alpha$-phellandrene in (a) a standard experiment (no. 10) and (b) an experiment that had formic acid added as a stabilised CI scavenger (no. 6). The red line represents the sample, whilst the black line is a preconditioned blank filter. Major negative mode ionisation peaks detected across all experiments (Table 2) are labelled.

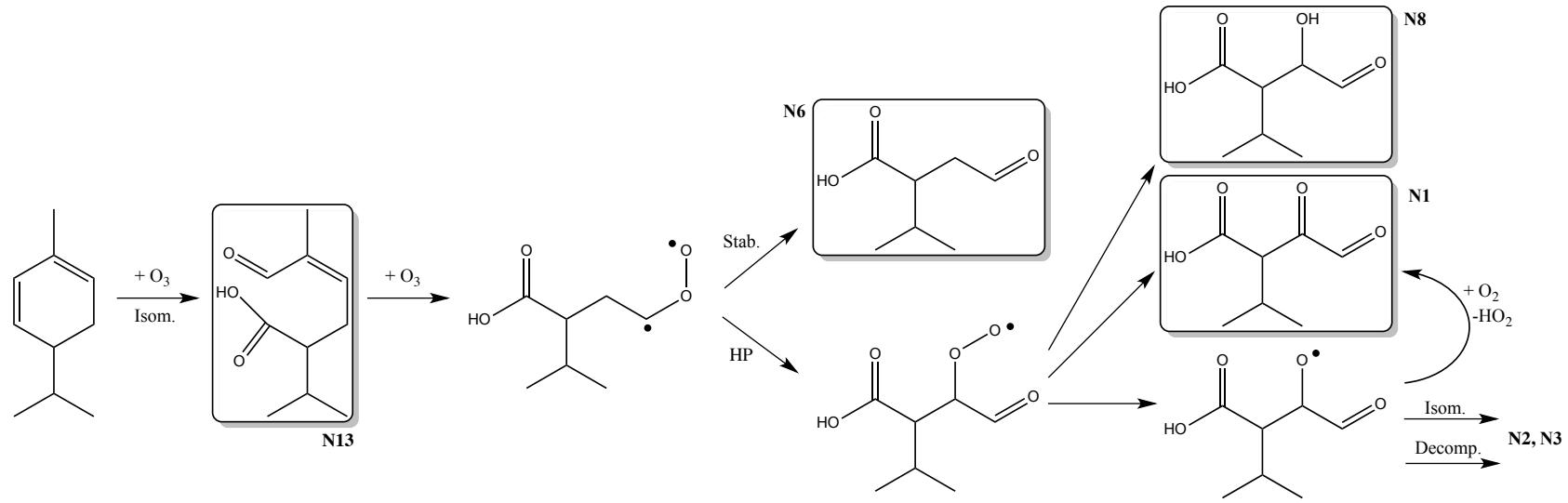

Figure 2. Simplified ozonolysis pathway outlining the formation of some major species detected in negative mode ESI. Analogous structures can additionally be traced by varying the order of addition to the two double bonds and/or which CIs participate in the hydroperoxide (HP) and stabilisation channels, respectively. 
Table 2. Major species detected in negative mode ESI with postulated structures consistent with composition, the mechanism proposed by Mackenzie-Rae et al. (2017) and tandem mass spectra. Estimated saturation vapour pressures $\left(P_{\text {vap }}\right)$ and saturation vapour concentrations $\left(C^{*}\right)$ for each product are also listed. The proposed structure list is not exhaustive, with other isomers existing.

\begin{tabular}{|c|c|c|c|c|c|c|}
\hline Product ID & Retention time (min) & Measured $m / z$ & Neutral formula & Possible structures & $\mathrm{P}_{\text {vap }}(\mathrm{atm})$ & $\mathrm{C}^{*}\left(\mu \mathrm{g} \mathrm{m}^{-3}\right)$ \\
\hline N1 & 3.81 & 157.05 & $\mathrm{C}_{7} \mathrm{H}_{10} \mathrm{O}_{4}$ & & $6 \times 10^{-7}$ & $4 \times 10^{3}$ \\
\hline $\mathrm{N} 2$ & 4.15 & 145.06 & $\mathrm{C}_{6} \mathrm{H}_{10} \mathrm{O}_{4}$ & & $4 \times 10^{-8}$ & $4 \times 10^{2}$ \\
\hline N3 & 4.86 & 187.06 & $\mathrm{C}_{7} \mathrm{H}_{8} \mathrm{O}_{6}$ & & $4 \times 10^{-11}$ & $4 \times 10^{-1}$ \\
\hline $\mathrm{N} 4$ & 5.01 & 175.06 & $\mathrm{C}_{7} \mathrm{H}_{12} \mathrm{O}_{5}$ & & $6 \times 10^{-11}$ & $6 \times 10^{-1}$ \\
\hline N5 & 5.39 & 175.06 & $\mathrm{C}_{7} \mathrm{H}_{12} \mathrm{O}_{5}$ & & $1 \times 10^{-10}$ & $1 \times 10^{0}$ \\
\hline N6 & 6.01 & 143.07 & $\mathrm{C}_{7} \mathrm{H}_{12} \mathrm{O}_{3}$ & & $6 \times 10^{-6}$ & $4 \times 10^{4}$ \\
\hline N7 & 6.23 & 143.07 & $\mathrm{C}_{7} \mathrm{H}_{12} \mathrm{O}_{3}$ & & $6 \times 10^{-6}$ & $4 \times 10^{4}$ \\
\hline N8 & 7.06 & 159.06 & $\mathrm{C}_{7} \mathrm{H}_{12} \mathrm{O}_{4}$ & & $5 \times 10^{-8}$ & $5 \times 10^{2}$ \\
\hline N9 & 7.51 & 215.09 & $\mathrm{C}_{10} \mathrm{H}_{16} \mathrm{O}_{5}$ & & $3 \times 10^{-12}$ & $2 \times 10^{-2}$ \\
\hline N10 & 7.96 & 173.08 & $\mathrm{C}_{8} \mathrm{H}_{14} \mathrm{O}_{4}$ & & $8 \times 10^{-6}$ & $3 \times 10^{4}$ \\
\hline N11 & 8.62 & 185.08 & $\mathrm{C}_{9} \mathrm{H}_{14} \mathrm{O}_{4}$ & & $3 \times 10^{-9}$ & $1 \times 10^{1}$ \\
\hline $\mathrm{N} 12$ & 9.69 & 199.08 & $\mathrm{C}_{10} \mathrm{H}_{16} \mathrm{O}_{4}$ & & $2 \times 10^{-9}$ & $1 \times 10^{1}$ \\
\hline $\mathrm{N} 13$ & 9.92 & 183.10 & $\mathrm{C}_{10} \mathrm{H}_{16} \mathrm{O}_{3}$ & & $3 \times 10^{-7}$ & $2 \times 10^{3}$ \\
\hline
\end{tabular}


attack at the least substituted double bond in $\alpha$-phellandrene is favoured, or the CI formed from ozonolysis of the more substituted double bond in $\alpha$-phellandrene is more likely to participate in the hydroperoxide channel than the CI from the less substituted double bond, both of which are consistent with recent theoretical findings (Mackenzie-Rae et al., 2016). Relative to compound N8, peak areas for $\mathrm{N} 4$ and $\mathrm{N} 5$ are suppressed upon introduction of $\mathrm{NO}_{2}$ into the system (experiment 11, also no cyclohexane). Similar inhibition is not observed in the other ozonolysis experiment where cyclohexane was not added (experiment 9); thus, it is concluded that it is the addition of $\mathrm{NO}_{2}$ to the system that precludes formation of compounds $\mathrm{N} 4$ and $\mathrm{N} 5$ by preferentially reacting with the acyl peroxy radical. Therefore, it is expected that compounds N4 and N5 become increasingly significant contributors to SOA generated from $\alpha$-phellandrene under increasingly " $\mathrm{NO}_{x}$-limited" conditions.

Peaks at retention times $4.15(\mathrm{~N} 2)$ and $4.86 \mathrm{~min}(\mathrm{~N} 3)$ are found consistently among the chromatograms from all samples and correspond to products with $[\mathrm{M}-\mathrm{H}]^{-}=m / z 145$ and 187 and neutral formulas of $\mathrm{C}_{6} \mathrm{H}_{10} \mathrm{O}_{4}$ and $\mathrm{C}_{7} \mathrm{H}_{8} \mathrm{O}_{6}$, respectively. The high oxygen content of both products indicates that at least one of the ozone additions decomposes through the hydroperoxide channel, with further intramolecular $\mathrm{H}$ transfers and oxygen additions possible throughout radical decomposition (Crounse et al., 2013; Kurtén et al., 2015). Proposed structures for compounds N2 and N3, derived from tandem mass spectra (Sect. S1), are given in Table 2.

Compounds N6 and N7 at retention times 6.01 and 6.23 min have a $[\mathrm{M}-\mathrm{H}]^{-}=m / z \quad 143$ and are assigned a neutral formula of $\mathrm{C}_{7} \mathrm{H}_{12} \mathrm{O}_{3}$. These species are formed through the CIs from both ozone additions being stabilised, resulting in aldehyde and carboxylic acid functionality as shown in Fig. 2 for N6. The impact of a SCI scavenger on the relative abundance of these species is discussed further in Sect. 3.5.

Observed in the majority of chromatograms, compound $\mathrm{N} 11$ has $[\mathrm{M}-\mathrm{H}]^{-}=m / z 185$ and a neutral formula of $\mathrm{C}_{9} \mathrm{H}_{14} \mathrm{O}_{4}$, with a diacid functionality proposed. However, gas-phase formation of N11 (Sect. S2) is only possible through a hydroperoxide pathway that has been shown by theoretical calculations to be uncompetitive (Mackenzie-Rae et al., 2016). Furthermore, whilst compound N11 shows consistency with the tandem spectrum, a loss of $88 \mathrm{Da}$ that may be expected for a diacid is not observed (Leenheer et al., 2001). Therefore, the proposed structure of compound N11 is only tentative and potentially involves unconsidered surface or condensed phase chemistry.

Compound N13 is present in all chromatograms as a major peak with a retention time of $9.92 \mathrm{~min}$ (except for experiment 11 which had $\mathrm{NO}_{2}$ added) and has $[\mathrm{M}-\mathrm{H}]^{-}=m / z, 183$ and a neutral formula of $\mathrm{C}_{10} \mathrm{H}_{16} \mathrm{O}_{3}$. The tandem mass spectrum is relatively uninformative, being dominated by a fragment ion at $m / z 139$, suggesting that loss of the carboxylic acid group results in a stable ion. Given this information, compound N13 is ascribed to the first-generation acids (Table 2), with the exact isomer unable to be determined. First-generation acids are predicted to be major first-generation products in the gas phase (Mackenzie-Rae et al., 2016), and so their detection in the particle phase is not surprising given their low estimated vapour pressures.

Compound N12, observed in all chromatograms, has a $[\mathrm{M}-\mathrm{H}]^{-}=m / z 199$ and is assigned a neutral formula of $\mathrm{C}_{10} \mathrm{H}_{16} \mathrm{O}_{4}$. As discussed in Sect. 3.5, the peak area of this species is reduced in the presence of a SCI scavenger. Only two main fragment ions are formed (loss of $\mathrm{CO}_{2}$ and $\mathrm{CO}_{2}+$ $\mathrm{H}_{2} \mathrm{O}$ ) and further fragmentation using $\mathrm{MS}^{3}$ yielded no additional ions. Two potential structures have been proposed. The first is a compound formed through the hydroperoxide channel undergoing a 1,6-H shift isomerisation, as proposed in Mackenzie-Rae et al. (2016), with a schematic shown in Fig. 4. However, this pathway would not be inhibited by the addition of a CI scavenger, as it is predominantly formed through rearrangement of excited CIs. Alternatively, N12 can be attributed to a diacid. One possibility is that the diacid forms through abstraction of the aldehydic hydrogen by the CI, as shown in Fig. 4. The mechanism, however, which was first proposed by Ma et al. (2007) to explain pinonic acid formation from $\alpha$-pinene, was shown to be uncompetitive with competing pathways using computational calculations (Mackenzie-Rae et al., 2016). An alternative prospect is that aldehyde groups are oxidised to carboxylic acids, increasing the mass by $16 \mathrm{Da}$, in a process that has been proposed to occur non-negligibly in the aerosol phase (Walser et al., 2008). For example, first-generation acids such as N13 could be oxidised to diacids through heterogeneous reaction with ozone. Therefore, the current proposal of compound N12 remains tentative. Similarly, compound N9, observed at a retention time of $7.51 \mathrm{~min}$, can form through oxidation of the carbonyl group in N12 to an acid. N9 is observed as a minor product in the majority of chromatograms, with a $[\mathrm{M}-\mathrm{H}]^{-}=m / z 215$ and a neutral formula of $\mathrm{C}_{10} \mathrm{H}_{16} \mathrm{O}_{5}$. The tandem mass spectrum is supportive of a diacid. Alternatively, the same product can be formed following the same pathway as N12 with an additional 1,7-H shift between the acyl groups before radical termination, as shown in Fig. 4.

\subsubsection{Positive mode}

Chromatograms produced from positive mode analysis are reasonably consistent across the experimental dataset, showing similar major product peaks, with the chromatogram from a representative experiment shown in Fig. 5. Tandem mass spectra from the positive mode however offer little structural insight, with identities of the major product peaks listed in Table 3 tentatively assigned based on mass-tocharge ratios and mechanistic insight (Mackenzie-Rae et al., 2016, 2017). Preference is given to structures containing at least one carbonyl group, consistent with positive mode ESI charging mechanics. Where overlap is observed with nega- 


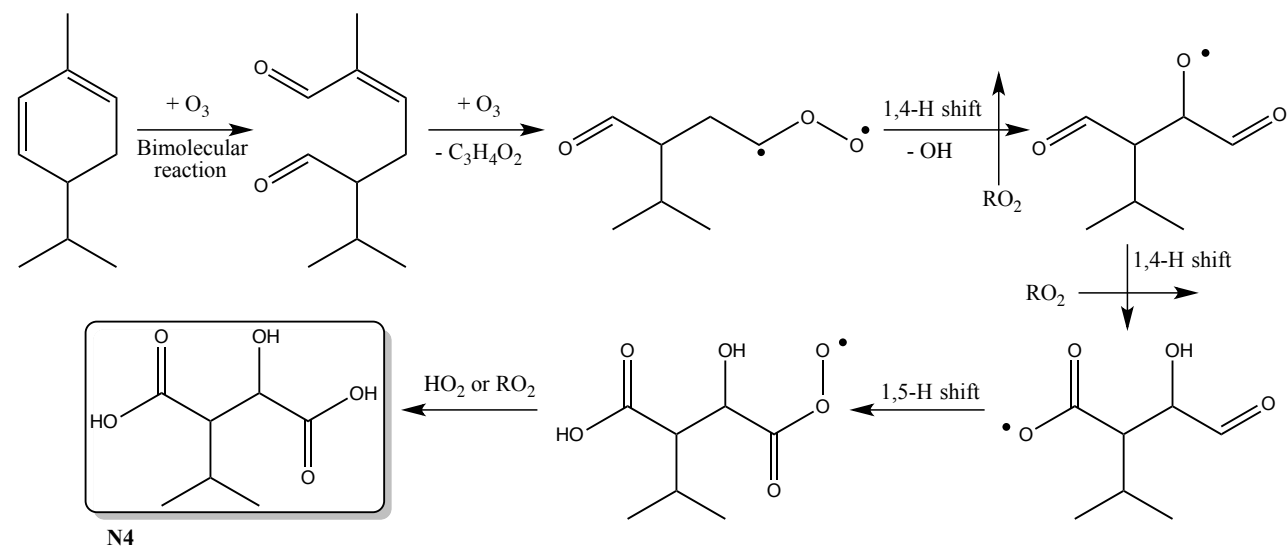

Figure 3. Proposed formation mechanism of compound N4. N5 is formed through an analogous mechanism starting with initial attack of ozone at the more substituted double bond. The vertical arrow with $\mathrm{RO}_{2}$ denotes a peroxy radical self-reaction to form an alkoxy radical.

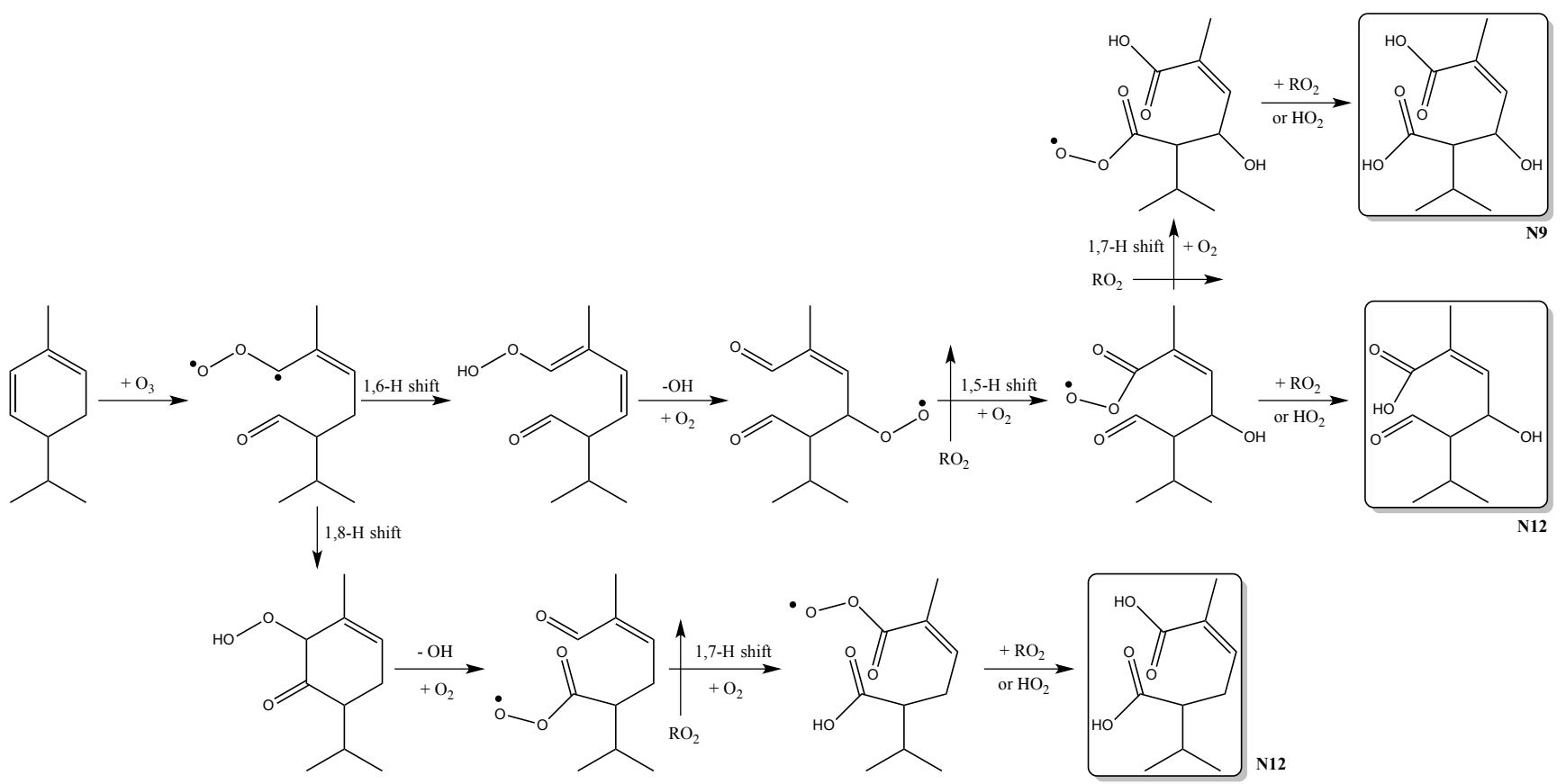

Figure 4. Formation mechanisms of compounds N9 and N12. Perpendicular arrows with $\mathrm{RO}_{2}$ denote peroxy radical self-reactions to form an alkoxy radical.

tive mode spectra, the same species are reassigned. For example, compound $\mathrm{N} 8$ is found in the positive mode at a similar retention time of $7.17 \mathrm{~min}$, with $[\mathrm{M}+\mathrm{Na}]^{+}=183$. Given this, the P3 hydroperoxide-containing isomer shown in Table 2 is assigned to the peak at $8.75 \mathrm{~min}$. A corollary is that acidic isomers detected in the negative mode are unlikely to be responsible for peaks in the positive mode if corresponding retention times are significantly different.

A dominant feature of all positive mode chromatograms is the large peak at retention time $5.06 \mathrm{~min}$, which has $[\mathrm{M}+\mathrm{Na}]^{+}=m / z \quad 151$ and is assigned a neutral formula of $\mathrm{C}_{7} \mathrm{H}_{12} \mathrm{O}_{2}$. This species is assigned to the major second- generation product $\mathrm{P} 1$, a dicarbonyl species. Similarly, compound $\mathrm{P} 2\left([\mathrm{M}-\mathrm{H}]^{-}=m / z 137, \mathrm{C}_{6} \mathrm{H}_{10} \mathrm{O}_{2}\right)$ is also a major dicarbonyl second-generation product, with $\mathrm{P} 1$ and $\mathrm{P} 2$ having both been detected in the gas phase (Mackenzie-Rae et al., 2017). Estimated vapour pressures support their primary residence in the gaseous phase (Fig. 6). However, given their expected high gas-phase concentrations, coupled with high aerosol loadings for most experiments inside the reactor, it is not unreasonable to assume considerable partitioning of these prominent intermediate-volatility gas-phase species (Leungsakul et al., 2005; Walser et al., 2008). In addition, 
Table 3. Major species detected in positive mode ESI with postulated structures consistent with composition and the mechanism proposed by Mackenzie-Rae et al. (2017), along with estimated saturation vapour pressures $\left(P_{\mathrm{vap}}\right)$ and saturation vapour concentrations $\left(C^{*}\right)$. Proposed structure list is not exhaustive, with other isomers existing.

\begin{tabular}{|c|c|c|c|c|c|c|}
\hline Product ID & Retention time (min) & Measured $m / z$ & Neutral formula & Possible structures & $P_{\text {vap }}(\mathrm{atm})$ & $\mathrm{C}^{*}\left(\mu \mathrm{g} \mathrm{m}^{-3}\right)$ \\
\hline P1 & 5.06 & 151.10 & $\mathrm{C}_{7} \mathrm{H}_{12} \mathrm{O}_{2}$ & & $2 \times 10^{-4}$ & $2 \times 10^{6}$ \\
\hline $\mathrm{P} 2$ & 6.04 & 137.10 & $\mathrm{C}_{6} \mathrm{H}_{10} \mathrm{O}_{2}$ & & $6-45 \times 10^{-4}$ & $4-35 \times 10^{6}$ \\
\hline P3 & $7.17,8.75$ & 183.10 & $\mathrm{C}_{7} \mathrm{H}_{12} \mathrm{O}_{4}$ & & $4-64 \times 10^{-8}$ & $3-48 \times 10^{2}$ \\
\hline P4 & 6.22 & 205.08 & $\mathrm{C}_{10} \mathrm{H}_{14} \mathrm{O}_{3}$ & & $4-12 \times 10^{-6}$ & $4-11 \times 10^{4}$ \\
\hline P5 & $6.88,9.03,9.36,9.60$ & 207.10 & $\mathrm{C}_{10} \mathrm{H}_{16} \mathrm{O}_{3}$ & & $0.3-700 \times 10^{-6}$ & $0.2-2930 \times 10^{4}$ \\
\hline P6 & $5.54,6.67,7.93,9.80$ & 223.11 & $\mathrm{C}_{10} \mathrm{H}_{16} \mathrm{O}_{4}$ & & $2-65 \times 10^{-9}$ & $1-40 \times 10^{1}$ \\
\hline $\mathrm{P} 7$ & 8.28 & 253.10 & $\mathrm{C}_{10} \mathrm{H}_{14} \mathrm{O}_{6}$ & & $2 \times 10^{-11}$ & $2 \times 10^{-1}$ \\
\hline P8 & 7.51 & 269.11 & $\mathrm{C}_{10} \mathrm{H}_{14} \mathrm{O}_{7}$ & & $5 \times 10^{-13}$ & $4 \times 10^{-3}$ \\
\hline
\end{tabular}

they may be present as a result of decomposition of larger species during the analysis (e.g. reverse oligomerisation).

The heaviest two products observed in the positive ionisation mode, $\mathrm{P} 7$ and $\mathrm{P} 8$, are attributed to peroxide-containing products from the hydroperoxide channel that have undergone additional intramolecular hydrogen abstractions and molecular oxygen additions. Termed autoxidation, this process has been used to explain aerosol formation from the reaction of monoterpenes with ozone in relatively clean environments, as it can result in the formation of compounds of extremely low volatility (Ehn et al., 2014; Jokinen et al.,
2015). As shown in Fig. 6, the estimated saturation vapour concentrations of P7 and P8 are not sufficient for nucleation. Nonetheless, their presence in the filter samples suggests autoxidation is occurring during $\alpha$-phellandrene oxidation, with it entirely possible that, upon further intramolecular $\mathrm{H}$ transfers, volatilities will be sufficiently reduced to form the extremely low-volatility compounds required for nucleation (Ehn et al., 2014; Jokinen et al., 2015). 


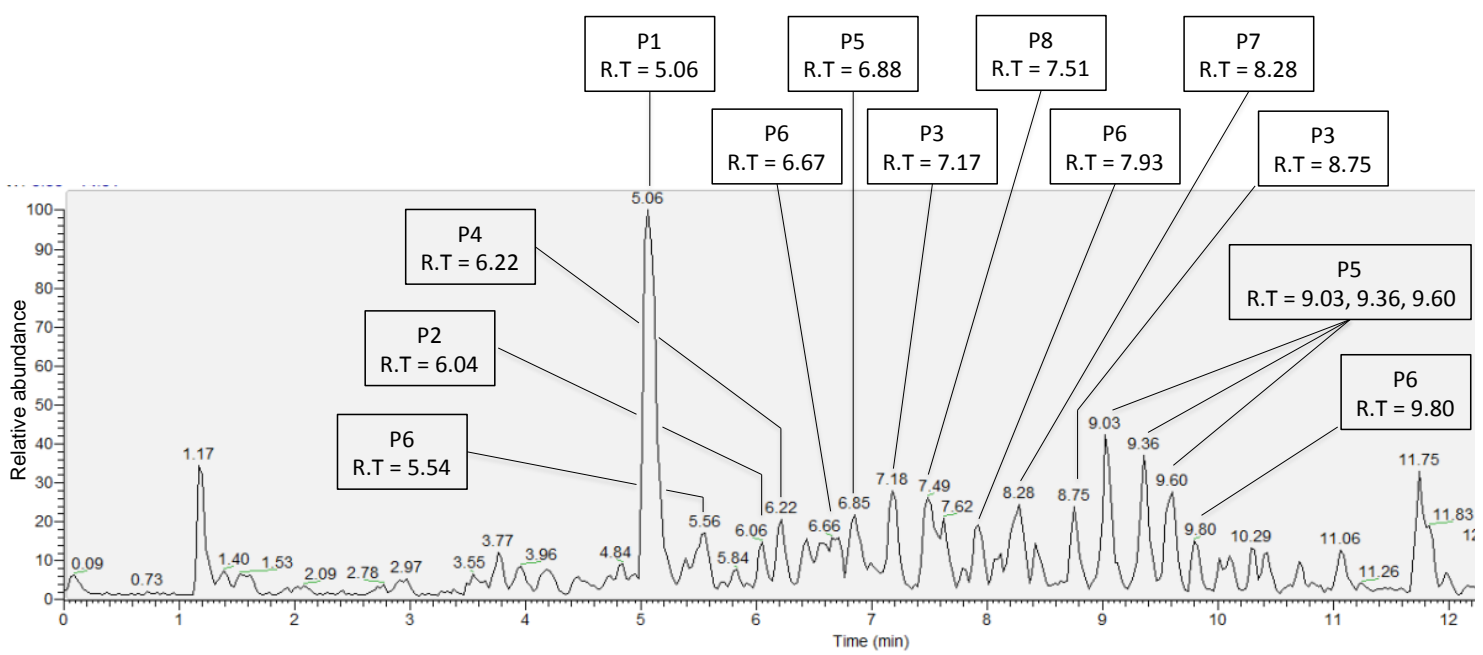

Figure 5. Positive ionisation mode chromatogram of SOA generated from the ozonolysis of $\alpha$-phellandrene (experiment 9). Major positive mode ionisation peaks detected across all experiments (Table 3) are labelled.

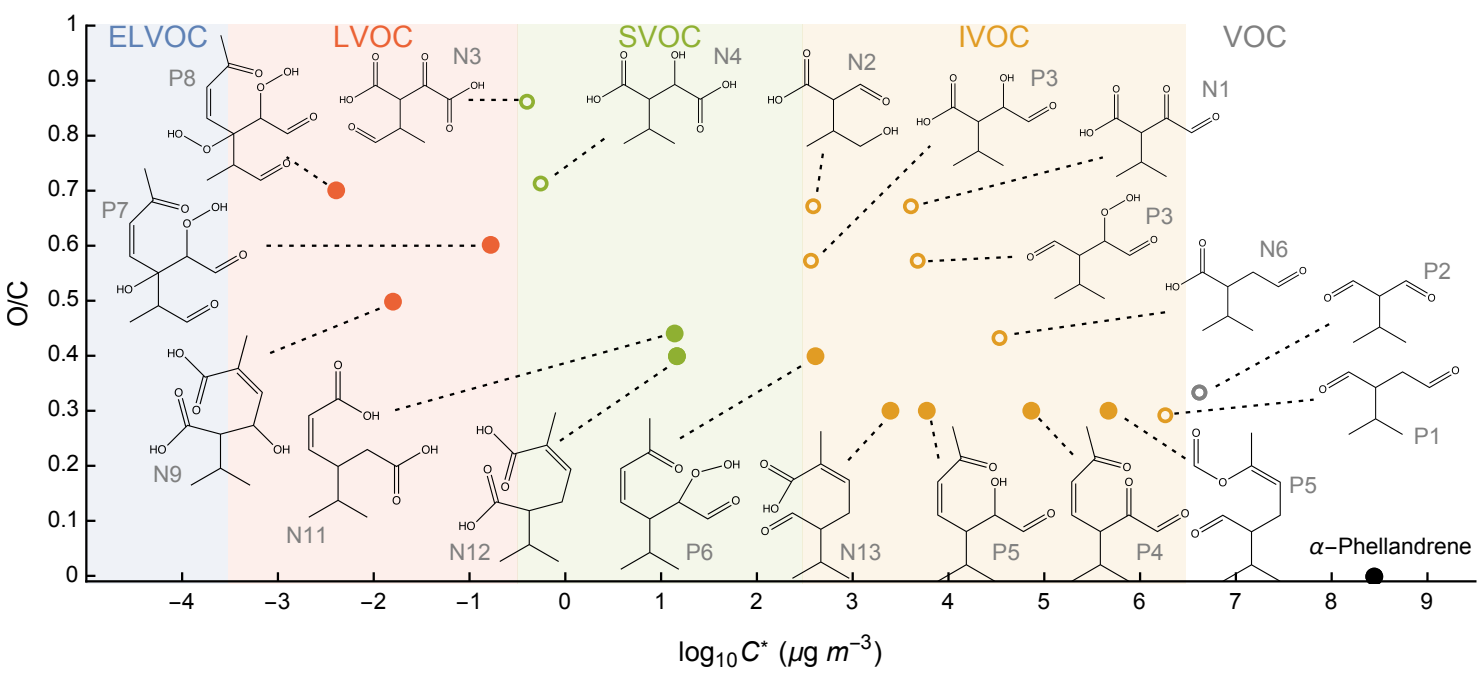

Figure 6. $\alpha$-Phellandrene and detected particle-phase ozonolysis products from both positive and negative ESI modes plotted in two dimensional volatility-oxidation space, constrained by saturation concentration on the $x$ axis and $\mathrm{O} / \mathrm{C}$ elemental ratios on the $y$ axis. Molecular structures of products are shown. Filled and open circles denote first- and second-generation products, respectively, with coloured regions indicating broad volatility classes. The volatility distribution can be compared with gas-phase species through Fig. 9 in Mackenzie-Rae et al. (2017).

\subsection{Product vapour pressures}

Whilst it was anticipated that the SOA would consist of a complex mixture of compounds, chromatographic analysis suggests that the SOA is instead dominated by a small number of major constituents. To assess the validity of identified products of differing functionalities as major aerosol constituents, saturation vapour concentrations $\left(\mathrm{C}^{*}, \mu \mathrm{g} \mathrm{m}^{-3}\right)$ for all predicted compounds were estimated using the method of Nannoolal et al. $(2004,2008)$ for vapour pressure and Zuend et al. $(2008,2011)$ for activity coefficients (method described in more detail in Sect. S3), with results provided in Tables 2 and 3 and plotted in two-dimensional volatilityoxidation space in Fig. 6. Vapour pressures were found to span almost 10 orders of magnitude, indicating considerable variability in volatilities of proposed particle-phase products. At the organic particle mass loadings found during the cham-

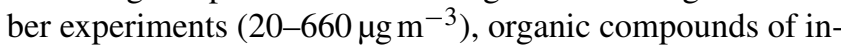
termediate volatility (IVOCs) are expected to primarily reside/partition into the gaseous phase and therefore be minor contributors to the particle phase (Donahue et al., 2012). Compounds classified as semi-volatile organics (SVOCs) are likely to have sizeable mass fractions in both the gaseous and aerosol phases at mass loadings encountered during chamber 
experiments, whilst those low-volatility organic compounds (LVOCs) are thought to exist predominantly in the particle phase (Donahue et al., 2006, 2012).

Figure 6 shows the most prominent peaks detected in both the positive and negative mode chromatograms (namely $m / z$ 160, 176, 184 and 200) are IVOCs and SVOCs. Three products were determined to be of low volatility, being $\mathrm{C}_{10}$ species with between five and seven oxygen atoms. Both first- and second-generation species are classified as SVOCs. Of the 21 products or product groups identified, 11 are $\mathrm{C}_{7}$ or smaller second-generation products, with the increase in volatility associated with losing at least three carbons compensated in part by the decrease in volatility resulting from increased functionalisation, as shown in Fig. 6. For both firstand second-generation products, there is a clear negative correlation between $\mathrm{C}^{*}$ and $\mathrm{O} / \mathrm{C}$, with an offset due to the size of the hydrocarbon backbone between generations.

Figure 6 shows that none of the major particle-phase species detected are classified as having extremely low volatility (ELVOCs), which has been argued as being a necessary requirement for compounds to homogenously nucleate upon supersaturation (Donahue et al., 2013; Heaton et al., 2007). The detected compounds are therefore unlikely to be responsible for the rapid burst of freshly nucleated aerosol observed upon $\alpha$-phellandrene reacting with ozone (Mackenzie-Rae et al., 2017), but rather they progressively condense onto the nucleated core once aerosol clusters have grown past a critical size. For the ozonolysis of other monoterpenes, ELVOC formation has been proposed to occur through gas-phase accretion reactions (Bateman et al., 2009; Camredon et al., 2010; Heaton et al., 2007, 2009; Lee and Kamens, 2005; Tolocka et al., 2004; Zhang et al., 2015) and autoxidation processes (Ehn et al., 2014; Jokinen et al., 2015). Higher mass compounds possibly formed as a result of these reaction pathways were detected in both positive and negative mode spectra, and are discussed further in the following section.

\subsection{High-resolution mass spectral analysis}

In order to investigate the overall composition of the SOA, an average mass spectrum was produced of the section of the chromatogram where SOA components eluted (i.e. not including the dead volume or the final gradient equilibrium period). Figure $7 \mathrm{a}$ shows a representative mass spectrum in the $m / z$ range 50-400 obtained in the positive mode (experiment 10 ). The spectrum contains over 280 peaks, with intensities exceeding $0.5 \%$ of the most abundant peak at $m / z$ 223. An example negative mode spectra is shown in Fig. $7 \mathrm{~b}$ and contains over 200 peaks in the $m / z$ range 50 450 , with intensities exceeding $0.5 \%$ of the most abundant peak at $m / z$ 199. In both spectra, peaks are predominantly clustered into wide groups separated by $14 \mathrm{amu}\left(\mathrm{CH}_{2}\right)$. The two spectra are explicitly compared in Fig. 7c by subtracting ${ }^{23} \mathrm{Na}$ from the positive mode spectrum and adding ${ }^{1} \mathrm{H}$ to the negative mode spectrum, making the plot pertinent to the neutral analytes. Depending on the experiment, either the peak at $m / z 160,176$ or 200 is the most intense. The compounds at $\mathrm{MW}=200 \mathrm{Da}$, where MW is molecular weight, correspond to the dominant first-generation SOA products at $\mathrm{C}_{10} \mathrm{H}_{16} \mathrm{O}_{4}$ (N12, $\mathrm{P} 6$ isomers), whereas the compounds at $\mathrm{MW}=160$ and $176 \mathrm{Da}$ correspond to the dominant secondgeneration SOA products at $\mathrm{C}_{7} \mathrm{H}_{12} \mathrm{O}_{4}(\mathrm{~N} 8, \mathrm{P} 3$ isomers) and $\mathrm{C}_{7} \mathrm{H}_{12} \mathrm{O}_{5}$ (N4 and N5), respectively. Therefore, the ratio of these is a reflection of the degree of oxidation that had occurred when the filter samples were collected. Other abundant peaks routinely found in both the positive and negative ion mode spectra include $m / z$ 144, 186 and 216, corresponding to products $\mathrm{N} 6 / \mathrm{N} 7, \mathrm{~N} 11$ and $\mathrm{N} 9$, respectively. There are some differences in the two spectra as a result of different ionisation efficiencies of SOA components. In addition, the larger downward peaks in the negative mode at $m / z 156$ and $m / z \quad 140$ in Fig. 7c are actually the result of a loss of $\mathrm{CO}_{2}$ due to "in-source" fragmentation from SOA components at $\mathrm{MW}=184 \mathrm{Da}$ and $\mathrm{MW}=200 \mathrm{Da}$. This highlights that caution is needed if a direct ESI with no prior separation approach is used. The assigned chemical formulas were also used to generate Kendrick plots, shown in the Supplement (Sect. S4), to investigate homologous families of molecules based on either $\mathrm{CH}_{2}\left(\mathrm{KM}_{\mathrm{CH}_{2}}\right)$ or $\mathrm{O}\left(\mathrm{KM}_{\mathrm{O}}\right)$ units. Although the spectral distribution is similar in both modes, there are sufficient differences that analysis of both ionisation modes is necessary for complete characterisation of SOA composition.

\subsection{Analysis of dimer products}

A recognisable feature of the mass spectra in both modes in Fig. 7 is the presence of monomers up to about $m / z 250$, followed by dimers from $m / z 250$ to 500 , corresponding to two oxygenated $\alpha$-phellandrene product units. Similar clustering of peaks in mass spectra from SOA generated by monoterpene ozonolysis has been extensively reported (Bateman et al., 2009; Camredon et al., 2010; Heaton et al., 2007; Reinhardt et al., 2007; Tolocka et al., 2004; Walser et al., 2008). The intensity of the oligomeric signals is lower than the major monomeric peaks and remains fairly consistent across the dimer domain. Proposed formulas range among $\mathrm{C}_{12-20} \mathrm{H}_{18-34} \mathrm{O}_{5-11}$. Whilst relative intensities are lower than monomeric species, dimers by nature contribute more mass and so are likely to have an important impact on the aerosol phase, especially in nucleation and early growth processes. Metrics such as $\mathrm{O} / \mathrm{C}$ and $\mathrm{H} / \mathrm{C}$ ratios, Kendrick mass defects and the double bond equivalency index (DBE) can be used to identify structural similarities and functionalities of SOA samples.

Species identified in the positive and negative modes, using the average mass spectra in Fig. 7, are plotted in Van Krevelen space in Fig. 8. The majority of products have $\mathrm{O} / \mathrm{C}$ ratios between 0.3 and 0.7 , and $\mathrm{H} / \mathrm{C}$ ratios between 

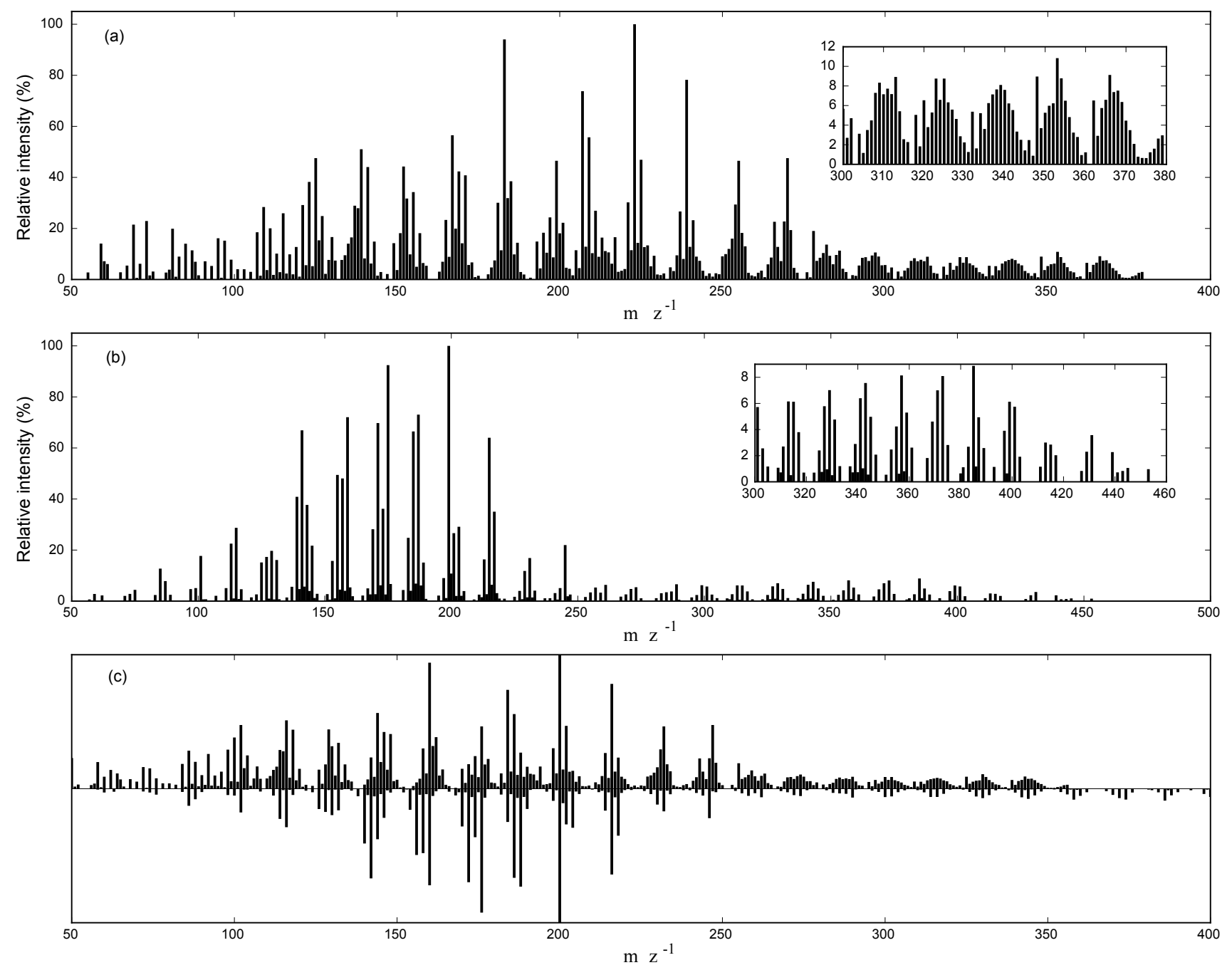

Figure 7. Representative ESI mass spectra from experiment 10 showing peaks with $\geq 0.5 \%$ abundance relative to the largest peak in the spectrum for stick spectra in the (a) positive and (b) negative modes. Comparison plot (c) shows mass spectra after subtracting ${ }^{23} \mathrm{Na}$ from the positive $m / z$ scale (up) and adding ${ }^{1} \mathrm{H}$ to the negative $m / z$ scale (down).

1.5 and 1.7. The species detected show significant variation in elemental composition, although no significant differences in the distribution between products detected in positive and negative modes were observed. Furthermore, the distribution of monomer and oligomer species is similar, with oligomers having a similar average $\mathrm{O} / \mathrm{C}$ but a narrower $\mathrm{O} / \mathrm{C}$ range.

Using assigned chemical formulas, DBEs were calculated for all major spectral peaks (RI $>5 \%$ ). Peaks containing an odd mass were taken as corresponding to molecules with one ${ }^{13} \mathrm{C}$ atom and were subsequently excluded. Calculated DBE values are plotted against carbon number in Fig. 9, with markers scaled by peak intensity (from SOA collected in experiment 10). The DBE values for major spectral components in the positive and negative modes were found to range from 2 to 5 , with the largest peaks being monomers with a DBE of 2 or 3 . The results suggest that most first-generation $\mathrm{C}_{10}$ products likely contain one $\mathrm{C}=\mathrm{C}$ double bond and two $\mathrm{C}=\mathrm{O}$ groups, whilst saturated second-generation $\mathrm{C}_{7}$ species contain two to three $\mathrm{C}=\mathrm{O}$ bonds.

Heavier oligomeric species have a DBE ranging from 3 to 5. A clear split can be seen in the SOA composition between monomers containing 10 or less carbons and oligomers. The smallest dimers at $\mathrm{C}_{12}$ are likely the result of reaction between two $\mathrm{C}_{6}$ monomers, whilst the group at $\mathrm{C}_{13}$ is likely the result of reaction between either a $\mathrm{C}_{6}$ and $\mathrm{C}_{7}$ monomer, or a $\mathrm{C}_{10}$ and a $\mathrm{C}_{3}$ product, formed from reaction at the second double bond. A further, more numerous group at $\mathrm{C}_{15}-\mathrm{C}_{20}$ is also seen and is likely a combination of a wider variety of $\mathrm{C}_{7}-\mathrm{C}_{10}$ species. Considering the DBEs of the base monomeric species, dimeric DBEs are consistent with oligomer formation through SCIs, peroxyhemiacetal and hemiacetal mechanisms. This is because the cu- 


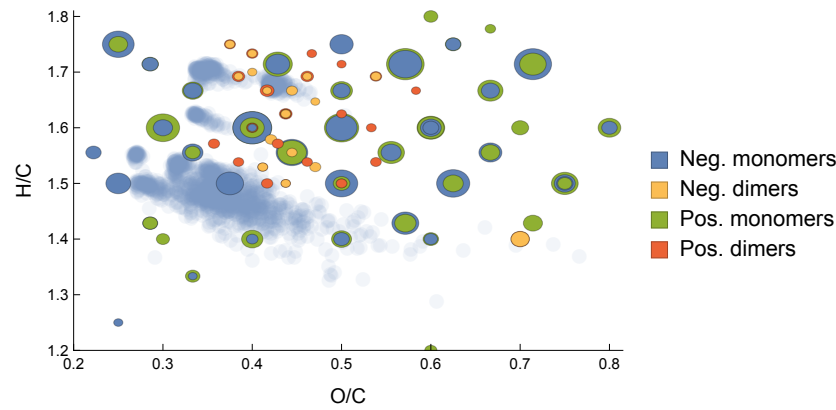

Figure 8. Van Krevelen plot comparing online experimental measurements by an AMS (blue shading) (Fig. 18 in Mackenzie-Rae et al., 2017) with assigned formulas from the ESI mass spectra $(\mathrm{RI}>5 \%)$ in the negative mode (blue $\leq \mathrm{C}_{10}$, yellow $>\mathrm{C}_{10}$ ) and positive mode (green $\leq \mathrm{C}_{10}$, red $>\mathrm{C}_{10}$ ). Circle size is proportional to relative signal intensity in either mode.

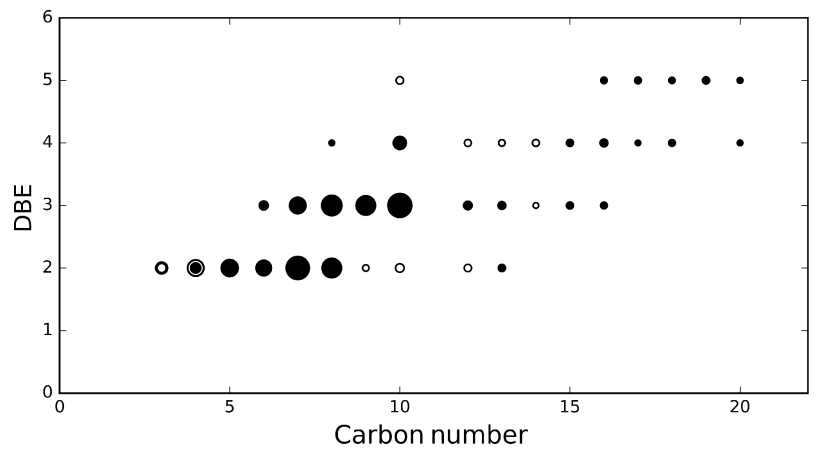

Figure 9. DBE values plotted against carbon number for ions (RI > $5 \%$ ) detected in the positive (open circle) and negative (closed circle) ionisation mode spectra from experiment 10 . The size of data points is proportional to signal intensity.

mulative DBE of two monomers decreases by 1 upon accretion through these mechanisms. In contrast, for oligomerisation pathways involving dehydration, such as aldol condensation and esterification, the DBE is additive when going from monomers to a dimer. Given the prominence of monomeric species with a DBE of 3, one would expect to see dimeric products with a DBE of 6 if condensation pathways were significant. Of the remaining considered accretion pathways, hemiacetal formation has previously been found to be thermodynamically unfavourable (Barsanti and Pankow, 2004), whilst peroxyhemiacetals are likely to be thermally labile and thus potentially unstable when subject to high temperatures during ESI ionisation (Camredon et al., 2010; Surratt et al., 2006). It is therefore concluded that oligomerisation through bimolecular reaction of SCIs is likely to be the major accretion process from $\alpha$-phellandrene ozonolysis under chamber simulation conditions.

Table 4 lists the mass of potential dimers that could be formed from the reaction of select SCIs with first- and second-generation products. The majority of the proposed masses from these bimolecular addition reactions were detected in the positive and negative ionisation mode mass spectra. In the literature, Bateman et al. (2009) proposed that the dominant oligomerisation mechanism in the ozonolysis of limonene is the reaction between SCIs and stable firstgeneration products, whilst Lee and Kamens (2005), Hall and Johnston (2012) and Kristensen et al. (2016) showed that reactions of SCIs with first-generation carboxylic acids are sources of dimers in the ozonolysis of $\alpha$-pinene. For isoprene ozonolysis, Sakamoto et al. (2017) argued that oligomerisation occurs through an initial reaction of an SCI with an organic acid, followed by sequential insertion of SCIs. This mechanism has support from their prior study into the ozonolysis of ethylene (Sakamoto et al., 2013). Meanwhile, for linear alkenes and enol ethers, Sadezky et al. (2006, 2008) and Y. Zhao et al. (2015) proposed that oligoperoxides, formed from the addition of SCIs to organic peroxy radicals, are responsible for SOA formation and growth. One important caveat is that smog chamber conditions are not entirely representative of the ambient, with these experiments conducted using artificially high precursor concentrations. Whereas in the atmosphere SCIs are largely scavenged by water or water dimers (Vereecken et al., 2015), the dry conditions and increased availability of organics inside the reactor increase propensity of the various SCI accretion channels.

In addition to formation from SCIs, numerous other accretion processes have been proposed in the literature to account for particle-phase oligomers including peroxyhemiacetal formation, hemiacetal formation, aldol condensation and acid anhydride and ester formation, which are summarised in reviews by Hallquist et al. (2009), Kroll and Seinfeld (2008) and Ziemann and Atkinson (2012). These processes have been proposed to occur in the gas phase, heterogeneously through reactive uptake on the surface of aerosols and/or via two condensed monomers. SOA products were detected at the $m / z$ values of dimers predicted to be formed via these pathways, with different monomer combinations, and accretion pathways, resulting in multiple dimeric products of the same mass. So whilst it is likely that the reaction of SCIs is important in forming dimers, significant contributions from other accretion channels cannot be readily discounted, with further investigation necessary to determine the relative importance of discussed dimerisation/oligomerisation channels.

\subsection{Impact of SCI scavenging on SOA composition}

Over the last decade, many studies have shown that SCIs are important precursors to SOA formation, using a range of SCI scavengers to investigate effects on yields, masses, number and composition of the particles formed. Recent results from Sakamoto et al. (2017) showed that SOA formation from isoprene ozonolysis was suppressed at high $\mathrm{RH}$ due to scavenging of the $\mathrm{CH}_{2} \mathrm{OO} \mathrm{SCI}$ through rapid reaction with water. However, a portion of the SCIs formed had lower reactivity towards water, mostly likely one or more of the correspond- 
Table 4. The $m / z$ values of possible dimer products from $\alpha$-phellandrene ozonolysis formed from the reaction of SCIs with non-radical ozonolysis products. Reaction of SCIs with carbonyls forms secondary ozonides whilst reaction with acids yields acyloxyalkyl hydroperoxides dimers. Masses in bold were reduced upon introduction of a SCI scavenger, masses in italics had increased abundance upon addition of a SCI scavenger, and masses in normal font remained similar or were inconsistent upon introduction of a SCI scavenger. ND denotes that the proposed mass was not detected in the ESI mass spectra.

\begin{tabular}{|c|c|c|c|c|c|c|c|c|c|}
\hline & & & & & speci & & & & \\
\hline & MW & 72 & 128 & 144 & 160 & 168 & 182 & 184 & 200 \\
\hline SCIs & 88 & ND & 216 & 232 & 248 & 256 & 270 & ND & 288 \\
\hline & 104 & ND & 232 & $\mathrm{ND}$ & 264 & ND & 286 & 288 & 304 \\
\hline & 144 & 216 & ND & 288 & 304 & 312 & 326 & 328 & 344 \\
\hline & 158 & 230 & 286 & 302 & 318 & 326 & ND & 342 & ND \\
\hline & 160 & 232 & 288 & 304 & 320 & 328 & 342 & 344 & 360 \\
\hline & 184 & 256 & 312 & 328 & 344 & 352 & ND & 368 & 384 \\
\hline
\end{tabular}

ing $\mathrm{C}_{4}$ SCI formed upon ozonolysis (Newland et al., 2015). In contrast, Kristensen et al. (2014) found that new particle formation and the amount of dimer-type molecules formed during $\alpha$-pinene ozonolysis increased at higher RH values. Bonn et al. (2002) reported a significant decrease in new particle formation and aerosol yields at higher $\mathrm{RH}$ values for the ozonolysis of exocyclic monoterpenes, with number concentration only moderately affected and no significant change in yield observed for the ozonolysis of endocyclic alkenes. Recent work from Newland et al. (2017) has shown that the reactions of certain $\mathrm{C}_{10} / \mathrm{C}_{9}$ monoterpene SCIs with water are slower than that for $\mathrm{CH}_{2} \mathrm{OO}$. Therefore, the reactivity of SCI with water is structurally dependent and may determine the effect of relative humidity on reducing SOA formed via SCI oligomerisation.

Zhao et al. (2016) found that particle number and higher molecular weight products formed from the ozonolysis of $\alpha$-cedrene, a $\mathrm{C}_{15}$ sesquiterpene, were significantly reduced upon addition of formic acid, $\mathrm{HC}(\mathrm{O}) \mathrm{OH}$, as a $\mathrm{SCI}$ scavenger. Ahmad et al. (2017) have recently shown that adding acetic acid or acetone to limonene ozonolysis experiments significantly delayed the formation of particles, leading to reduced SOA masses and a reduction in particle numbers, with acetic acid showing the strongest effect. These findings are consistent with the study of Bonn et al. (2002), who showed the addition of formic acid to have a significant inhibiting effect on nucleation and on total aerosol volume for the ozonolysis of $\beta$-pinene, with similar but less drastic changes reported for $\alpha$-pinene. Similar observations were also reported in the companion paper using formic acid as an SCI scavenger in the $\alpha$-phellandrene ozonolysis experiments, with SCI scavenged experiments showing a large reduction in initial particle number concentrations, suggesting a reduction in 
the number of SOA-nucleating agents and lower total SOA yields (Part 1, Mackenzie-Rae et al., 2017).

In order to investigate the impact of the SCI on the formation of dimers and SOA composition more generally, a series of experiments was carried out with high concentrations of formic acid (Table 1, experiments 6 and 7). Figure 1 shows the main differences in the chromatograms from SCI scavenged experiments were an increase in the relative amount of compounds $\mathrm{N} 10$ and N7, and a decrease in the amount of compounds $\mathrm{N} 12$ and N13. Compound N10 has $[\mathrm{M}-\mathrm{H}]^{-}=m / z 173$ and is assigned a neutral formula of $\mathrm{C}_{8} \mathrm{H}_{14} \mathrm{O}_{4}$. It is a relatively minor species in the majority of filter samples; however, it is observed as a major peak at retention time $7.96 \mathrm{~min}$ in the chromatograms of SOA produced with formic acid added as a SCI radical scavenger (experiments 6 and 7). Tandem mass spectra offer some insight, with losses of 44 and $62 \mathrm{Da}$ (carboxylic acid and an other oxygenated functional group). A small fragment ion at $m / z 83\left(\mathrm{C}_{5} \mathrm{H}_{7} \mathrm{O}\right)$ indicates a carbonyl or acid functionality in the $\alpha$ position to the branched side chain. The structure contains eight carbons, suggesting it is formed via reaction of a $\mathrm{C}_{7}$ second-generation product and formic acid. The scavenging mechanism of SCI by formic acid is known to form a hydroperoxy methyl formate (HPMF) for the $\mathrm{CH}_{2} \mathrm{OO}$ SCI (Neeb et al., 1995; Hasson et al., 2001; Sakamoto et al., 2013). Horie et al. (1997) have detected 1hydroperoxyethyl formate (HPEF) using FTIR spectrometry in cis/trans-but-2-ene ozonolysis experiments in the presence of formic acid, which decomposes to acetic formic acid anhydride. Liu et al. (2015) have also looked at the reaction of a range of alkyl-substituted SCI with deuterated formic acid and acetic acid using photoelectron spectroscopy, directly detecting a range of partially deuterated alkyl-substituted vinyl hydroperoxide species formed through an acid-catalysed tautomerisation reaction. Complementary theoretical calculations predict several reaction pathways, including a barrierless insertion reaction to yield a hydroperoxyalkyl formate (Liu et al., 2015; Kumar et al., 2014). An equivalent functionalised hydroperoxy alkyl formate is shown in Fig. 10 for a major second-generation SCI (Mackenzie-Rae et al., 2017). However, the established mechanism cannot explain the formation of the observed product, as dehydration to an acid anhydride species (Neeb et al., 1995; Horie et al., 1997) forms a product with a mass $2 \mathrm{Da}$ too low. An alternative decomposition process is therefore required to explain formation of N10 from the major second-generation CIs. It is therefore proposed that formic acid can additionally participate in accretion reactions with products, driven by the high concentrations of formic acid inside the reactor. An example is given in Fig. 10, yielding the predicted product through a hemiacetaltype reaction (c.f. Hallquist et al., 2009). Whilst the proposed product could potentially match the MS/MS spectrum, the thermodynamics of its formation remain uncertain. Because aerosol yields were observed to decrease upon the addition of formic acid (Mackenzie-Rae et al., 2017), the net effect of the increased product contribution of N10 to the condensed phase is less than that which originates from SCIs in nonscavenged experiments.

There is also a more pronounced peak at retention time $6.23 \mathrm{~min}$ (N7) in the formic acid experiments. The two peaks at retention time $6.01 \mathrm{~min}$ and retention time $6.23 \mathrm{~min}$ are structural isomers of $\mathrm{C}_{7} \mathrm{H}_{12} \mathrm{O}_{3}$ with the acid and carbonyl functionalities on different sides of the molecule. The $\mathrm{MS}^{2}$ spectra are almost identical (loss of 44 and $46 \mathrm{Da}$; see Fig. S1.6 and S1.7), with the peak at 6.23 min having a small additional peak from loss of $\mathrm{CO}(28 \mathrm{Da})$, suggesting the carbonyl is in the $\alpha$ position to the branched chain. The structural similarity and enhanced formation of both N7 and N10 upon addition of formic acid suggests that there may be an intrinsic relationship between the two species. One possibility is that N7 is a decomposition product of N10 or other dimeric species formed through SCI scavenging.

The two major peaks that have significantly reduced peak intensities are both $\mathrm{C}_{10}$ species, containing carbonyl and acidic functionalities $\left(\mathrm{N} 12=\mathrm{C}_{10} \mathrm{H}_{16} \mathrm{O}_{4}\right.$ and $\left.\mathrm{N} 13=\mathrm{C}_{10} \mathrm{H}_{16} \mathrm{O}_{3}\right)$. This result further suggests that these structurally similar species are related, with $\mathrm{N} 12$ being formed from further oxidation of N13. The absence of a N13 peak when $\mathrm{NO}_{2}$ is present suggests that formation is inhibited by $\mathrm{NO}_{2}$, which would also scavenge SCIs to form carbonyls. Interestingly, N13 is only moderately impacted when using formic acid as the SCI scavenger, implying that scavenging by formic acid may ultimately result in evolution of acid functionality, either through further degradation or catalysing CI tautomerisation (Kumar et al., 2014; Liu et al., 2015).

The experiments with formic acid were both carried out at low initial $\alpha$-phellandrene mixing ratios $(<20 \mathrm{ppb})$. The average mass spectra for scavenged and non-scavenged experiments carried out at very low concentrations do not show the obvious dimer region seen in Fig. 7, most likely as a result of increased background interferences. In order to assess the change in the oligomer composition, the extracted ion chromatograms were compared for two experiments with and without formic acid but with similar levels of initial VOCs (experiments 3 and 7). The changes in the relative $m / z$ peak areas associated with the products of reactions of the main SCIs with a range of stable carbonyl and acids for scavenged and unscavenged experiments were estimated and are shown in Table 4. A direct comparison of peak areas is complicated due to (a) a large difference in the amount of SOA mass produced (121 vs. $28 \mathrm{mg} \mathrm{m}^{-3}$ ), which will change the volatility distribution of SOA, (b) differences in ozone levels in the chamber and (c) the fact that dimers from different reaction pathways can result in dimers of the same mass. However, there are clear differences in the distribution of dimers between the two experiments. A total of seven dimer mass peaks $\left(\mathrm{MW}=288,304\left(\mathrm{C}_{14}\right), 312,328,344\right.$, 352, $368 \mathrm{Da}$; bold numbers in Table 4) showed a reduced peak area when the scavenger was used. A total of four dimer 


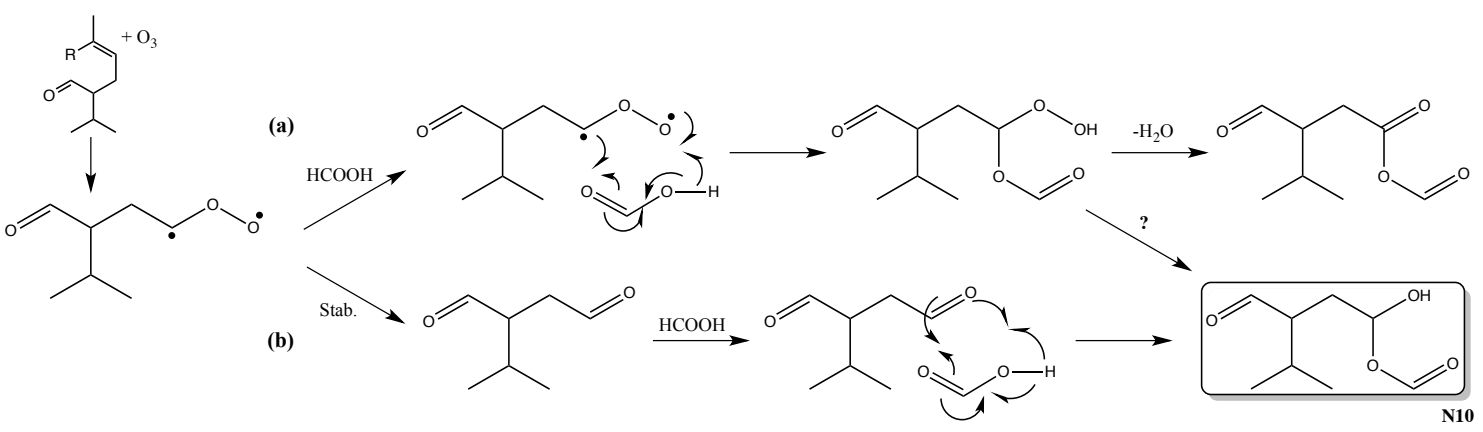

Figure 10. Reaction of (a) prominent second-generation CI with formic acid and (b) accretion of major second-generation carbonyl with formic acid to yield proposed structure for compound N10. An unknown channel is required to join pathway (a) with product N10.

masses $\left(\mathrm{MW}=256,270,302,304\left(\mathrm{C}_{13}\right) \mathrm{Da}\right.$; italicised in Table 4) were more abundant when the scavenger was used. The remainder of masses in Table 4 show either similar peak areas or have inconsistencies; for example, the extracted ion chromatogram of $m / z 341(M=342 \mathrm{Da})$ has two peaks: one that is similar in both samples and one that is reduced in the presence of formic acid. The number of high mass oligomers was also significantly suppressed upon addition of $\mathrm{NO}_{2}$ to the system, with $\mathrm{NO}_{2}$ also acting as a sink for SCIs (Welz et al., 2012).

The observed change in oligomeric species distributions upon the addition of a SCI scavenger may help to explain macroscopic observations, where the number of aerosol particles observed during the initial stages of experiments was found to decrease upon addition of formic acid (MackenzieRae et al., 2017). The measured reaction rates of $C_{1}$ and $C_{2}$ $\mathrm{SCI}$ with formic acid have been measured to be very fast, in excess of $1 \times 10^{-10} \mathrm{~cm}^{3} \mathrm{~s}^{-1}$, several orders of magnitude faster than reaction with water $\left(\sim 1 \times 10^{-16} \mathrm{~cm}^{3} \mathrm{~s}^{-1}\right.$; Welz et al., 2014). Given that the concentrations of water inside the reactor was 3 orders of magnitude larger than the concentration of formic acid (Table 1), the results presented here for $\alpha$-phellandrene suggest that scavenging of the SCI by small carboxylic acids is much faster than the sink reaction with water and can lead to a significant drop in the amount of dimers and hence SOA that is formed, with potentially important atmospheric implications (Sipilä et al., 2014). Further work is needed to gain a holistic understanding of SCI chemistry, principally in identifying the chemical pathways that lead to dimer formation from SCIs and characterising the chemical impact of SCI scavengers such as water, $\mathrm{NO}_{x}$, $\mathrm{SO}_{2}$ and oxygenated volatile organic compounds (i.e. acids, carbonyls, alcohols) on atmospheric aerosol composition.

\section{Conclusions}

The compositional components of the organic aerosol formed from the gas-phase ozonolysis of $\alpha$-phellandrene were identified and characterised for the first time, using a high-resolution quadrupole-Orbitrap mass spectrometer. In total, 21 products or product groups were identified from chromatograms, aided by tandem mass spectrometry, with electrospray ionisation used in both positive and negative modes to gain complementary compositional information. Both polyfunctional first- and second-generation products were found to be prominent in the aerosol, with products significantly more complex than those proposed from basic gas-phase chemistry in the companion paper (MackenzieRae et al., 2017). The results therefore suggest that a number of first-generation unsaturated products are sufficiently volatile to remain in the gas phase and further react with ozone, with many of the resultant second-generation products able to partition into the particle phase despite saturation vapour concentration estimates classifying a large number of products as semi-volatile. Oligomeric species are observed in both positive and negative mode spectra, with evidence supporting dimerisation through bimolecular reactions of stabilised Criegee intermediates. Suppression of oligomer spectral peaks upon the addition of a stabilised Criegee intermediate scavenger coincided with reduced experimental SOA growth and formation, with stabilised Criegee intermediate dimers, and/or higher-order oligomers, believed to be a significant source of the highly condensable products required for the rapid nucleation and growth of new particles observed in the system (Mackenzie-Rae et al., 2017). Further investigation is required, however, to better characterise the role of stabilised Criegee intermediates in the system, to parameterise the specific accretion mechanisms occurring and to determine the origin of the high vapour pressure compounds that correspond to the large positive mode signals. Nonetheless, this study has provided the first understanding of the nature of SOA formed from the ozonolysis of $\alpha$-phellandrene, and more generally contributes to an enhanced knowledge of the atmospheric effects and implications of monoterpene emissions.

Data availability. Labelled tandem mass spectra for all identified products are provided in the Supplement. Data files con- 
taining the average mass spectrum in positive and negative ionisation for experiments $6,7,9$ and 10 , along with $\mathrm{C}^{*}$ calculations and the $\mathrm{O}: \mathrm{C}$ ratios of proposed products, are publicly available at https://doi.org/10.15124/83f745b4-dfd6-491a9b84-0bd7eeaa01ec (Mackenzie-Rae et al., 2018). Further raw data are available on request.

\section{The Supplement related to this article is available online at https://doi.org/10.5194/acp-18-4673-2018-supplement.}

Competing interests. The authors declare that they have no conflict of interest.

Acknowledgements. The authors would like to thank Tengyu Liu, Wei Deng, Zheng Fang and Yanli Zhang for their assistance in collecting the filter samples. Felix Mackenzie-Rae acknowledges support from the Wolfson Atmospheric Chemistry Laboratories in the Department of Chemistry at the University of York, for a 2month visiting position in order to collaborate on the filter sample data analysis, and the UWA Postgraduate Student Association and Convocation of UWA Graduates for travel funding. Chamber experiments were made possible through funding by the Strategic Priority Research Program of the Chinese Academy of Sciences (grant no. XDB05010200), Ministry of Science and Technology of China (grant no. 2016YFC0202204) and National Natural 10 Science Foundation of China (grant no. 41530641/41571130031). The Orbitrap MS was funded through a UK Natural Environment Research Council Capital Grant (NERC grant CC090).

Edited by: Frank Keutsch

Reviewed by: two anonymous referees

\section{References}

Ahmad, W., Coeur, C., Cuisset, A., Coddeville, P., and Tomas, A.: Effects of scavengers of Criegee intermediates and $\mathrm{OH}$ radicals on the formation of secondary organic aerosol in the ozonolysis of limonene, J. Aerosol Sci., 110, 70-83, https://doi.org/10.1016/j.jaerosci.2017.05.010, 2017.

Atkinson, R. and Arey, J.: Gas-phase tropospheric chemistry of biogenic volatile organic compounds: A review, Atmos. Environ., 37, S197-S219, https://doi.org/10.1016/S1352-2310(03)00391$1,2003$.

Barsanti, K. C. and Pankow, J. F.: Thermodynamics of the formation of atmospheric organic particulate matter by accretion reactionsPart 1: aldehydes and ketones, Atmos. Environ., 38, 4371-4382, https://doi.org/10.1016/j.atmosenv.2004.03.035, 2004.

Bateman, A. P., Nizkorodov, S. A., Laskin, J., and Laskin, A.: Time-resolved molecular characterization of limonene/ozone aerosol using high-resolution electrospray ionization mass spectrometry, Phys. Chem. Chem. Phys., 11, 7931-7942, https://doi.org/10.1039/b916865f, 2009.
Bonn, B., Schuster, G., and Moortgat, G. K.: Influence of water vapor on the process of new particle formation during monoterpene ozonolysis, J. Phys. Chem. A, 106, 2869-2881, https://doi.org/10.1021/jp012713p, 2002.

Brook, R. D., Rajagopalan, S., Pope, C. A., Brook, J. R., Bhatnagar, A., Diez-Roux, A. V., Holguin, F., Hong, Y., Luepker, R. V., Mittleman, M. A., Peters, A., Siscovick, D., Smith, S. C., Whitsel, L., and Kaufman, J. D.: Particulate matter air pollution and cardiovascular disease: An update to the scientific statement from the american heart association, Circulation, 121, 2331-2378, https://doi.org/10.1161/CIR.0b013e3181dbece1, 2010.

Brophy, J. J. and Southwell, I. A.: Eucalyptus Chemistry, in: Eucalyptus: The Genus Eucalyptus., edited by: Coppen, J. J. W., Taylor \& Francis, London, UK, 2002.

Camredon, M., Hamilton, J. F., Alam, M. S., Wyche, K. P., Carr, T., White, I. R., Monks, P. S., Rickard, A. R., and Bloss, W. J.: Distribution of gaseous and particulate organic composition during dark $\alpha$-pinene ozonolysis, Atmos. Chem. Phys., 10, 2893-2917, https://doi.org/10.5194/acp-10-2893-2010, 2010.

Carslaw, K. S., Boucher, O., Spracklen, D. V., Mann, G. W., Rae, J. G. L., Woodward, S., and Kulmala, M.: A review of natural aerosol interactions and feedbacks within the Earth system, Atmos. Chem. Phys., 10, 1701-1737, https://doi.org/10.5194/acp10-1701-2010, 2010.

Crounse, J. D., Nielsen, L. B., Jørgensen, S., Kjaergaard, H. G., and Wennberg, P. O.: Autoxidation of Organic Compounds in the Atmosphere, J. Phys. Chem. Lett., 4, 3513-3520, https://doi.org/10.1021/jz4019207, 2013.

DeCarlo, P. F., Kimmel, J. R., Trimborn, A., Northway, M. J., Jayne, J. T., Aiken, A. C., Gonin, M., Fuhrer, K., Horvath, T., Docherty, K. S., Worsnop, D. R., and Jimenez, J. L.: Field-deployable, high-resolution, time-offlight aerosol mass spectrometer, Anal. Chem., 78, 8281-8289, https://doi.org/10.1021/ac061249n, 2006.

Donahue, N. M., Robinson, A. L., Stanier, C. O., and Pandis, S. N.: Coupled partitioning, dilution, and chemical aging of semivolatile organics, Environ. Sci. Technol., 40, 2635-2643, https://doi.org/10.1021/es052297c, 2006.

Donahue, N. M., Henry, K. M., Mentel, T. F., Kiendler-Scharr, A., Spindler, C., Bohn, B., Brauers, T., Dorn, H. P., Fuchs, H., Tillmann, R., Wahner, A., Saathoff, H., Naumann, K.-H., Möhler, O., Leisner, T., Müller, L., Reinnig, M.-C., Hoffmann, T., Salo, K., Hallquist, M., Frosch, M., Bilde, M., Tritscher, T., Barmet, P., Praplan, A. P., DeCarlo, P. F., Dommen, J., Prévôt, A. S. H., and Baltensperger, U.: Aging of biogenic secondary organic aerosol via gas-phase $\mathrm{OH}$ radical reactions, P. Natl. Acad. Sci. USA, 109, 13503-13508, https://doi.org/10.1073/pnas.1115186109, 2012.

Donahue, N. M., Ortega, I. K., Chuang, W., Riipinen, I., Riccobono, F., Schobesberger, S., Dommen, J., Baltensperger, U., Kulmala, M., Worsnop, D. R., and Vehkamaki, H.: How do organic vapors contribute to new-particle formation?, Faraday Discuss., 165, 91-104, https://doi.org/10.1039/c3fd00046j, 2013.

Ehn, M., Thornton, J. A., Kleist, E., Sipilä, M., Junninen, H., Pullinen, I., Springer, M., Rubach, F., Tillmann, R., Lee, B., Lopez-Hilfiker, F., Andres, S., Acir, I.-H., Rissanen, M., Jokinen, T., Schobesberger, S., Kangasluoma, J., Kontkanen, J., Nieminen, T., Kurtén, T., Nielsen, L. B., Jørgensen, S., Kjaergaard, H. G., Canagaratna, M., Maso, M. D., Berndt, T., Petäjä, T., Wahner, A., Kerminen, V.-M., Kulmala, M., 
Worsnop, D. R., Wildt, J., and Mentel, T. F.: A large source of low-volatility secondary organic aerosol, Nature, 506, 476-479, https://doi.org/10.1038/nature13032, 2014.

Emmerson, K. M., Galbally, I. E., Guenther, A. B., Paton-Walsh, C., Guerette, E.-A., Cope, M. E., Keywood, M. D., Lawson, S. J., Molloy, S. B., Dunne, E., Thatcher, M., Karl, T., and Maleknia, S. D.: Current estimates of biogenic emissions from eucalypts uncertain for southeast Australia, Atmos. Chem. Phys., 16, 6997-7011, https://doi.org/10.5194/acp-16-6997-2016, 2016.

Fuentes, J. D., Lerdau, M., Atkinson, R., Baldocchi, D., Bottenheim, J. W., Ciccioli, P., Lamb, B., Geron, C., Gu, L., Guenther, A., Sharkey, T. D., and Stockwell, W.: Biogenic Hydrocarbons in the Atmospheric Boundary Layer: A Review, B. Am. Meteorol. Soc., 81, 1537-1575, https://doi.org/10.1175/15200477(2000)081<1537:BHITAB>2.3.CO;2, 2000.

Gao, S., Keywood, M., Ng, N. L., Surratt, J., Varutbangkul, V., Bahreini, R., Flagan, R. C., and Seinfeld, J. H.: LowMolecular-Weight and Oligomeric Components in Secondary Organic Aerosol from the Ozonolysis of Cycloalkenes and $\alpha$-pinene, J. Phys. Chem. A, 108, 10147-10164, https://doi.org/10.1021/jp047466e, 2004.

Geron, C., Rasmussen, R., Arnts, R. R., and Guenther, A.: A review and synthesis of monoterpene speciation from forests in the United States, Atmos. Environ., 34, 1761-1781, https://doi.org/10.1016/S1352-2310(99)00364-7, 2000.

Griffin, R. J., Cocker, D. R., Flagan, R. C., and Seinfeld, J. H.: Organic aerosol formation from the oxidation of biogenic hydrocarbons, J. Geophys. Res., 104, 3555-3567, https://doi.org/10.1029/1998JD100049, 1999.

Guenther, A., Hewitt, C. N., Erickson, D., Fall, R., Geron, C., Graedel, T., Harley, P., Klinger, L., Lerdau, M., McKay, W. A., Pierce, T., Scholes, B., Steinbrecher, R., Tallamraju, R., Taylor, J., and Zimmerman, P.: A global model of natural volatile organic compound emissions, J. Geophys. Res., 100, 8873-8892, https://doi.org/10.1029/94JD02950, 1995.

Guenther, A. B., Jiang, X., Heald, C. L., Sakulyanontvittaya, T., Duhl, T., Emmons, L. K., and Wang, X.: The Model of Emissions of Gases and Aerosols from Nature version 2.1 (MEGAN2.1): an extended and updated framework for modeling biogenic emissions, Geosci. Model Dev., 5, 1471-1492, https://doi.org/10.5194/gmd-5-1471-2012, 2012.

Hall, W. A. and Johnston, M. V.: Oligomer formation pathways in secondary organic aerosol from MS and MS/MS measurements with high mass accuracy and resolving power, J. Am. Soc. Mass Spectrom., 23, 1097-1108, https://doi.org/10.1007/s13361-0120362-6, 2012

Hallquist, M., Wenger, J. C., Baltensperger, U., Rudich, Y., Simpson, D., Claeys, M., Dommen, J., Donahue, N. M., George, C., Goldstein, A. H., Hamilton, J. F., Herrmann, H., Hoffmann, T., Iinuma, Y., Jang, M., Jenkin, M. E., Jimenez, J. L., Kiendler-Scharr, A., Maenhaut, W., McFiggans, G., Mentel, Th. F., Monod, A., Prévôt, A. S. H., Seinfeld, J. H., Surratt, J. D., Szmigielski, R., and Wildt, J.: The formation, properties and impact of secondary organic aerosol: current and emerging issues, Atmos. Chem. Phys., 9, 5155-5236, https://doi.org/10.5194/acp9-5155-2009, 2009.

Hamilton, J. F., Lewis, A. C., Carey, T. J., and Wenger, J. C.: Characterization of polar compounds and oligomers in secondary organic aerosol using liquid chromatography cou- pled to mass spectrometry, Anal. Chem., 80, 474-480, https://doi.org/10.1021/Ac701852t, 2008.

Hasson, A. S., Orzechowska, G., and Paulson, S. E.: Production of stabilized Criegee intermediates and peroxides in the gas phase ozonolysis of alkenes: 1 . Ethene, trans-2-butene, and 2,3-dimethyl-2-butene, J. Geophys. Res., 106, 34131-34142, https://doi.org/10.1029/2001JD000597, 2001.

He, C., Murray, F., and Lyons, T.: Monoterpene and isoprene emissions from 15 Eucalyptus species in Australia, Atmos. Environ., 34, 645-655, https://doi.org/10.1016/S1352-2310(99)00219-8, 2000.

Heaton, K. J., Dreyfus, M. A., Wang, S., and Johnston, M. V.: Oligomers in the early stage of biogenic secondary organic aerosol formation and growth, Environ. Sci. Technol., 41, 61296136, https://doi.org/10.1021/es070314n, 2007.

Heaton, K. J., Sleighter, R. L., Hatcher, P. G., Hall, W. A., and Johnston, M. V.: Composition domains in monoterpene secondary organic aerosol, Environ. Sci. Technol., 43, 7797-7802, https://doi.org/10.1021/es901214p, 2009.

Hoffmann, T., Odum, J. R., Bowman, F., Collins, D., Klockow, D., Flagan, R. C., and Seinfeld, J. H.: Formation of organic aerosols from the oxidation of biogenic hydrocarbons, J. Atmos. Chem. 26, 189-222, https://doi.org/10.1023/A:1005734301837, 1997.

Horie, O., Neeb, P., and Moortgat, G. K.: The reactions of the Criegee intermediate $\mathrm{CH}_{3} \mathrm{CHOO}$ in the gas-phase ozonolysis of 2-butene isomers, Int. J. Chem. Kinet., 29, 461-468, https://doi.org/10.1002/(SICI)1097-4601(1997)29:6<461::AIDKIN8>3.0.CO;2-S, 1997.

IPCC: Summary for Policymakers, in: Climate Change 2013: The Physical Science Basis, edited by: Stocker, T. F., Qin, D., Plattner, G.-K., Tignor, M., Allen, S. K., Boschung, J., Nauels, A., Xia, Y., Bex, V., and Midgley, P. M., Cambridge University Press, Cambridge, UK and New York, NY, USA, 2013.

Jayne, J. T., Leard, D. C., Zhang, X., Davidovits, P., Smith, K. A., Kolb, C. E., and Worsnop, D. R.: Development of an aerosol mass spectrometer for size and composition analysis of submicron particles, Aerosol Sci. Tech., 33, 49-70, https://doi.org/10.1080/027868200410840, 2000

Jimenez, J. L., Canagaratna, M. R., Donahue, N. M., Prevot, A. S. H., Zhang, Q., Kroll, J. H., Decarlo, P. F., Allan, J. D., Coe, H., Ng, N. L., Aiken, A. C., Ulbrich, I. M., Grieshop, A. P., Duplissy, J., Wilson, K. R., Lanz, V. A., Hueglin, C., Sun, Y. L., Tian, J., Laaksonen, A., Raatikainen, T., Rautiainen, J., Vaattovaara, P., Ehn, M., Kulmala, M., Tomlinson, J. M., Cubison, M. J., Dunlea, E. J., Alfarra, M. R., Williams, P. I., Bower, K., Kondo, Y., Schneider, J., Drewnick, F., Borrmann, S., Weimer, S., Demerjian, K., Salcedo, D., Cottrell, L., Takami, A., Miyoshi, T., Shimono, A., Sun, J. Y., Zhang, Y. M., Dzepina, K., Sueper, D., Jayne, J. T., Herndon, S. C., Williams, L. R., Wood, E. C., Middlebrook, A. M., Kolb, C. E., Baltensperger, U., and Worsnop, D. R.: Evolution of organic aerosols in the atmosphere, Science, 326, 1525-1529, https://doi.org/10.1126/science.1180353, 2009.

Johnson, D. and Marston, G.: The gas-phase ozonolysis of unsaturated volatile organic compounds in the troposphere, Chem. Soc. Rev., 37, 699-716, https://doi.org/10.1039/b704260b, 2008.

Jokinen, T., Berndt, T., Makkonen, R., Kerminen, V.-M., Junninen, H., Paasonen, P., Stratmann, F., Herrmann, H., Guenther, A. B., Worsnop, D. R., Kulmala, M., Ehn, M., and Sip- 
ilä, M.: Production of extremely low volatile organic compounds from biogenic emissions: Measured yields and atmospheric implications, P. Natl. Acad. Sci. USA, 112, 7123-7128, https://doi.org/10.1073/pnas.1423977112, 2015.

Kanakidou, M., Seinfeld, J. H., Pandis, S. N., Barnes, I., Dentener, F. J., Facchini, M. C., Van Dingenen, R., Ervens, B., Nenes, A., Nielsen, C. J., Swietlicki, E., Putaud, J. P., Balkanski, Y., Fuzzi, S., Horth, J., Moortgat, G. K., Winterhalter, R., Myhre, C. E. L., Tsigaridis, K., Vignati, E., Stephanou, E. G., and Wilson, J.: Organic aerosol and global climate modelling: a review, Atmos. Chem. Phys., 5, 1053-1123, https://doi.org/10.5194/acp-5-10532005, 2005.

Kesselmeier, J., Kuhn, U., Wolf, A., Andreae, M. O., Ciccioli, P., Brancaleoni, E., Frattoni, M., Guenther, A., Greenberg, J., De Castro Vasconcellos, P., De Oliva, T., Tavares, T., and Artaxo, P.: Atmospheric volatile organic compounds (VOC) at a remote tropical forest site in central Amazonia, Atmos. Environ., 34, 4063-4072, https://doi.org/10.1016/S1352-2310(00)00186$2,2000$.

Kristensen, K., Cui, T., Zhang, H., Gold, A., Glasius, M., and Surratt, J. D.: Dimers in $\alpha$-pinene secondary organic aerosol: effect of hydroxyl radical, ozone, relative humidity and aerosol acidity, Atmos. Chem. Phys., 14, 4201-4218, https://doi.org/10.5194/acp-14-4201-2014, 2014.

Kristensen, K., Watne, A. K., Hammes, J., Lutz, A., Petäjä, T., Hallquist, M., Bilde, M., and Glasius, M.: High-Molecular Weight Dimer Esters Are Major Products in Aerosols from $\alpha$-Pinene Ozonolysis and the Boreal Forest, Environ. Sci. Tech. Let., 3, 280-285, https://doi.org/10.1021/acs.estlett.6b00152, 2016.

Kroll, J. H. and Seinfeld, J. H.: Chemistry of secondary organic aerosol: Formation and evolution of low-volatility organics in the atmosphere, Atmos. Environ., 42, 3593-3624, https://doi.org/10.1016/j.atmosenv.2008.01.003, 2008.

Kumar, M., Busch, D. H., Subramaniam, B., and Thompson, W. H.: Barrierless tautomerization of Criegee intermediates via acid catalysis, Phys. Chem. Chem. Phys., 16, 22968-22973, https://doi.org/10.1039/c4cp03065f, 2014.

Kurtén, T., Rissanen, M. P., Mackeprang, K., Thornton, J. A., Hyttinen, N., Jørgensen, S., Ehn, M., and Kjaergaard, H. G.: Computational study of hydrogen shifts and ring-opening mechanisms in $\alpha$-pinene ozonolysis products, J. Phys. Chem. A, 119, 1136611375, https://doi.org/10.1021/acs.jpca.5b08948, 2015.

Lee, S. and Kamens, R. M.: Particle nucleation from the reaction of $\alpha$-pinene and $\mathrm{O}_{3}$, Atmos. Environ., 39, 6822-6832, https://doi.org/10.1016/j.atmosenv.2005.07.062, 2005.

Lee, S.-H., Young, L.-H., Benson, D. R., Suni, T., Kulmala, M., Junninen, H., Campos, T. L., Rogers, D. C., and Jensen, J.: Observations of nighttime new particle formation in the troposphere, J. Geophys. Res., 113, D10210, https://doi.org/10.1029/2007JD009351, 2008.

Leenheer, J. A., Rostad, C. E., Gates, P. M., Furlong, E. T., and Ferrer, I.: Molecular Resolution and Fragmentation of Fulvic Acid by Electrospray Ionization/Multistage Tandem Mass Spectrometry, Anal. Chem., 73, 1461-1471, https://doi.org/10.1021/ac0012593, 2001.

Leungsakul, S., Jaoui, M., and Kamens, R. M.: Kinetic mechanism for predicting secondary organic aerosol formation from the reaction of d-limonene with ozone, Environ. Sci. Technol., 39, 9583-9594, https://doi.org/10.1021/es0492687, 2005.
Li, H., Madden, J. L., and Potts, B. M.: Variation in volatile leaf oils of the tasmanian Eucalyptus species-1. Subgenus Monocalyptus, Biochem. Syst. Ecol., 23, 299-318, https://doi.org/10.1016/0305-1978(95)97455-6, 1995.

Liu, F., Fang, Y., Kumar, M., Thompson, W. H., and Lester, M. I.: Direct observation of vinyl hydroperoxide, Phys. Chem. Chem. Phys., 17, 20490-20494, 2015.

Ma, Y., Willcox, T. R., Russell, A. T., and Marston, G.: Pinic and pinonic acid formation in the reaction of ozone with $\alpha$-pinene, Chem. Commun., 13, 1328-1330, https://doi.org/10.1039/b617130c, 2007.

Mackenzie-Rae, F. A., Karton, A., and Saunders, S. M.: Computational investigation into the gas-phase ozonolysis of the conjugated monoterpene $\alpha$-phellandrene, Phys. Chem. Chem. Phys., 18, 27991-28002, https://doi.org/10.1039/C6CP04695A, 2016.

Mackenzie-Rae, F. A., Liu, T., Deng, W., Saunders, S. M., Fang, Z., Zhang, Y., and Wang, X.: Ozonolysis of $\alpha$-phellandrene - Part 1: Gas- and particle-phase characterisation, Atmos. Chem. Phys., 17, 6583-6609, https://doi.org/10.5194/acp-176583-2017, 2017.

Mackenzie-Rae, F. A., Wallis, H. J., Rickard, A. R., Pereira, K., Saunders, S. M., Wang, X., Hamilton, J. F.: Suplementary data for paper: Ozonolysis of $\alpha$-phellandrene - Part 2: Compositional analysis of secondary organic aerosol highlights the role of stabilised Criegee intermediates, https://doi.org/10.15124/83f745b4-dfd6-491a-9b840bd7eeaa01ec, 2018

Maghsoodlou, M. T., Kazemipoor, N., Valizadeh, J., Falak Nezhad Seifi, M., and Rahneshan, N.: Essential oil composition of Eucalyptus microtheca and Eucalyptus viminalis, Avicenna J. Phytomedicine, 5, 540-552, 2015.

Maleknia, S. D., Bell, T. L., and Adams, M. A.: Eucalypt smoke and wildfires: Temperature dependent emissions of biogenic volatile organic compounds, Int. J. Mass Spectrom., 279, 126133, https://doi.org/10.1016/j.ijms.2008.10.027, 2009.

Myburg, A. A., Grattapaglia, D., Tuskan, G. A., Hellsten, U., Hayes, R. D., Grimwood, J., Jenkins, J., Lindquist, E., Tice, H., Bauer, D., Goodstein, D. M., Dubchak, I., Poliakov, A., Mizrachi, E., Kullan, A. R. K., Hussey, S. G., Pinard, D., van der Merwe, K., Singh, P., van Jaarsveld, I., Silva-Junior, O. B., Togawa, R. C., Pappas, M. R., Faria, D. A., Sansaloni, C. P., Petroli, C. D., Yang, X., Ranjan, P., Tschaplinski, T. J., Ye, C.Y., Li, T., Sterck, L., Vanneste, K., Murat, F., Soler, M., Clemente, H. S., Saidi, N., Cassan-Wang, H., Dunand, C., Hefer, C. A., Bornberg-Bauer, E., Kersting, A. R., Vining, K., Amarasinghe, V., Ranik, M., Naithani, S., Elser, J., Boyd, A. E., Liston, A., Spatafora, J. W., Dharmwardhana, P., Raja, R., Sullivan, C., Romanel, E., Alves-Ferreira, M., Külheim, C., Foley, W., Carocha, V., Paiva, J., Kudrna, D., Brommonschenkel, S. H., Pasquali, G., Byrne, M., Rigault, P., Tibbits, J., Spokevicius, A., Jones, R. C., Steane, D. A., Vaillancourt, R. E., Potts, B. M., Joubert, F., Barry, K., Pappas Jr., G. J., Strauss, S. H., Jaiswal, P., Grima-Pettenati, J., Salse, J., Van de Peer, Y., Rokhsar, D. S., and Schmutz, J.: The genome of Eucalyptus grandis, Nature, 510, 356-362, https://doi.org/10.1038/nature13308, 2014.

Nannoolal, Y., Rarey, J., Ramjugernath, D., and Cordes, W.: Estimation of pure component properties Part 1. Estimation of the normal boiling point of non-electrolyte organic compounds via group contributions and group interactions, Fluid Phase Equi- 
libr., 226, 45-63, https://doi.org/10.1016/j.fluid.2004.09.001, 2004.

Nannoolal, Y., Rarey, J., and Ramjugernath, D.: Estimation of pure component properties Part 3. Estimation of the vapor pressure of non-electrolyte organic compounds via group contribution and group interactions, Fluid Phase Equilibr., 269, 117-133, https://doi.org/10.1016/j.fluid.2008.04.020, 2008.

Neeb, P., Horie, O., and Moortgat, G. K.: The nature of the transitory product in the gas-phase ozonolysis of ethene, Chem. Phys. Lett., 246, 150-156, https://doi.org/10.1016/00092614(95)01073-I, 1995.

Newland, M. J., Rickard, A. R., Vereecken, L., Muñoz, A., Ródenas, M., and Bloss, W. J.: Atmospheric isoprene ozonolysis: impacts of stabilised Criegee intermediate reactions with $\mathrm{SO}_{2}$, $\mathrm{H}_{2} \mathrm{O}$ and dimethyl sulfide, Atmos. Chem. Phys., 15, 9521-9536, https://doi.org/10.5194/acp-15-9521-2015, 2015.

Newland, M. J., Rickard, A. R., Sherwen, T., Evans, M. J., Vereecken, L., Muñoz, A., Ródenas, M., and Bloss, W. J.: The atmospheric impacts of monoterpene ozonolysis on global stabilised Criegee intermediate budgets and $\mathrm{SO} 2$ oxidation: experiment, theory and modelling, Atmos. Chem. Phys. Discuss., https://doi.org/10.5194/acp-2017-1095, in review, 2017.

Niki, H., Maker, P. D., Savage, C. M., Breitenbach, L. P., and Hurley, M. D.: FTIR spectroscopic study of the mechanism for the gas-phase reaction between ozone and tetramethylethylene, J. Phys. Chem., 91, 941-946, https://doi.org/10.1021/j100288a035, 1987.

Ortega, I. K., Suni, T., Boy, M., Grönholm, T., Manninen, H. E., Nieminen, T., Ehn, M., Junninen, H., Hakola, H., Hellén, H., Valmari, T., Arvela, H., Zegelin, S., Hughes, D., Kitchen, M., Cleugh, H., Worsnop, D. R., Kulmala, M., and Kerminen, V.-M.: New insights into nocturnal nucleation, Atmos. Chem. Phys., 12, 4297-4312, https://doi.org/10.5194/acp-12-4297-2012, 2012.

Pavlova, L. V., Platonov, I. A., Nikitchenko, N. V., and Novikova, E. A.: Evaluation of the efficiency of volatile organic compounds extraction from Eucalyptus viminalis (Eucalypti viminalis Labill) using subcritical extractants, Russ. J. Phys. Chem. B, 9, 1109-1115, https://doi.org/10.1134/S1990793115080084, 2015.

Pope, C. A. and Dockery, D. W.: Health Effects of Fine Particulate Air Pollution: Lines that Connect, J. Air Waste Manage., 56, 709-742, https://doi.org/10.1080/10473289.2006.10464485, 2006.

Ramasamy, S., Ida, A., Jones, C., Kato, S., Tsurumaru, H., Kishimoto, I., Kawasaki, S., Sadanaga, Y., Nakashima, Y., Nakayama, T., Matsumi, Y., Mochida, M., Kagami, S., Deng, Y., Ogawa, S., Kawana, K., and Kajii, Y.: Total OH reactivity measurement in a BVOC dominated temperate forest during a summer campaign, 2014, Atmos. Environ., 131, 41-54, https://doi.org/10.1016/j.atmosenv.2016.01.039, 2016.

Reinhardt, A., Emmenegger, C., Gerrits, B., Panse, C., Dommen, J., Baltensperger, U., Zenobi, R., and Kalberer, M.: Ultrahigh mass resolution and accurate mass measurements as a tool to characterize oligomers in secondary organic aerosols, Anal. Chem., 79, 4074-4082, https://doi.org/10.1021/ac062425v, 2007.

Sadezky, A., Chaimbault, P., Mellouki, A., Römpp, A., Winterhalter, R., Le Bras, G., and Moortgat, G. K.: Formation of secondary organic aerosol and oligomers from the ozonolysis of enol ethers,
Atmos. Chem. Phys., 6, 5009-5024, https://doi.org/10.5194/acp6-5009-2006, 2006.

Sadezky, A., Winterhalter, R., Kanawati, B., Römpp, A., Spengler, B., Mellouki, A., Le Bras, G., Chaimbault, P., and Moortgat, G. K.: Oligomer formation during gas-phase ozonolysis of small alkenes and enol ethers: new evidence for the central role of the Criegee Intermediate as oligomer chain unit, Atmos. Chem. Phys., 8, 2667-2699, https://doi.org/10.5194/acp-8-2667-2008, 2008.

Sakamoto, Y., Inomata, S., and Hirokawa, J.: Oligomerization reaction of the Criegee intermediate leads to secondary organic aerosol formation in ethylene ozonolysis, J. Phys. Chem. A, 117, 12912-12921, https://doi.org/10.1021/jp408672m, 2013.

Sakamoto, Y., Yajima, R., Inomata, S., and Hirokawa, J.: Water vapour effects on secondary organic aerosol formation in isoprene ozonolysis, Phys. Chem. Chem. Phys., 19, 3165-3175, https://doi.org/10.1039/C6CP04521A, 2017.

Saxton, J. E., Lewis, A. C., Kettlewell, J. H., Ozel, M. Z., Gogus, F., Boni, Y., Korogone, S. O. U., and Serça, D.: Isoprene and monoterpene measurements in a secondary forest in northern Benin, Atmos. Chem. Phys., 7, 4095-4106, https://doi.org/10.5194/acp-7-4095-2007, 2007.

Sipilä, M., Jokinen, T., Berndt, T., Richters, S., Makkonen, R., Donahue, N. M., Mauldin III, R. L., Kurtén, T., Paasonen, P., Sarnela, N., Ehn, M., Junninen, H., Rissanen, M. P., Thornton, J., Stratmann, F., Herrmann, H., Worsnop, D. R., Kulmala, M., Kerminen, V.-M., and Petäjä, T.: Reactivity of stabilized Criegee intermediates (sCIs) from isoprene and monoterpene ozonolysis toward $\mathrm{SO}_{2}$ and organic acids, Atmos. Chem. Phys., 14, 1214312153, https://doi.org/10.5194/acp-14-12143-2014, 2014.

Suni, T., Kulmala, M., Hirsikko, A., Bergman, T., Laakso, L., Aalto, P. P., Leuning, R., Cleugh, H., Zegelin, S., Hughes, D., van Gorsel, E., Kitchen, M., Vana, M., Hõrrak, U., Mirme, S., Mirme, A., Sevanto, S., Twining, J., and Tadros, C.: Formation and characteristics of ions and charged aerosol particles in a native Australian Eucalypt forest, Atmos. Chem. Phys., 8, 129-139, https://doi.org/10.5194/acp-8-129-2008, 2008.

Surratt, J. D., Murphy, S. M., Kroll, J. H., Ng, N. L., Hildebrandt, L., Sorooshian, A., Szmigielski, R., Vermeylen, R., Maenhaut, W., Claeys, M., Flagan, R. C., and Seinfeld, J. H.: Chemical composition of secondary organic aerosol formed from the photooxidation of isoprene, J. Phys. Chem. A, 110, 9665-9690, https://doi.org/10.1021/jp061734m, 2006.

Tolocka, M. P., Jang, M., Ginter, J. M., Cox, F. J., Kamens, R. M., and Johnston, M. V.: Formation of oligomers in secondary organic aerosol, Environ. Sci. Technol., 38, 1428-1434, https://doi.org/10.1021/es035030r, 2004.

Vereecken, L., Glowacki, D. R., and Pilling, M. J.: Theoretical Chemical Kinetics in Tropospheric Chemistry: Methodologies and Applications, Chem. Rev., 115, 4063-4114, https://doi.org/10.1021/cr500488p, 2015.

Walser, M. L., Desyaterik, Y., Laskin, J., Laskin, A., and Nizkorodov, S. A.: High-resolution mass spectrometric analysis of secondary organic aerosol produced by ozonation of limonene, Phys. Chem. Chem. Phys., 10, 1009-1022, https://doi.org/10.1039/B712620D, 2008.

Wang, S. C. and Flagan, R. C.: Scanning electrical mobility spectrometer, Aerosol Sci. Tech., 13, 230-240, https://doi.org/10.1016/0021-8502(89)90868-9, 1990. 
Wang, X., Liu, T., Bernard, F., Ding, X., Wen, S., Zhang, Y., Zhang, Z., He, Q., Lü, S., Chen, J., Saunders, S., and Yu, J.: Design and characterization of a smog chamber for studying gas-phase chemical mechanisms and aerosol formation, Atmos. Meas. Tech., 7, 301-313, https://doi.org/10.5194/amt-7301-2014, 2014.

Warnke, J., Bandur, R., and Hoffmann, T.: Capillary-HPLCESI-MS/MS method for the determination of acidic products from the oxidation of monoterpenes in atmospheric aerosol samples, Anal. Bioanal. Chem., 385, 34-45, https://doi.org/10.1007/s00216-006-0340-6, 2006.

Welz,O., Savee, J. D., Osborn, D. L., Vasu, S. S., Percival, C. J., Shallcross, D. E., and Taatjes, C. A.: Direct kinetic measurements of Criegee intermediate $\left(\mathrm{CH}_{2} \mathrm{OO}\right)$ formed by reaction of $\mathrm{CH}_{2} \mathrm{I}$ with $\mathrm{O}_{2}$, Science, 335, 204-207, 2012.

Welz, O., Eskola, A. J., Sheps, L., Rotavera, B., Savee, J. D., Scheer, A. M., Osborn, D. L., Lowe, D., Murray Booth, A., Xiao, P., Anwar H. Khan, M., Percival, C. J., Shallcross, D. E., and Taatjes, C. A.: Rate Coefficients of $\mathrm{C} 1$ and C2 Criegee Intermediate Reactions with Formic and Acetic Acid Near the Collision Limit: Direct Kinetics Measurements and Atmospheric Implications, Angew. Chem. Int. Ed., 53, 4547-4550, https://doi.org/10.1002/anie.201400964, 2014.

Winterhalter, R., Herrmann, F., Kanawati, B., Nguyen, T. L., Peeters, J., Vereecken, L., and Moortgat, G. K.: The gasphase ozonolysis of $\beta$-caryophyllene $\left(\mathrm{C}_{15} \mathrm{H}_{24}\right)$. Part I: an experimental study, Phys. Chem. Chem. Phys., 11, 4152-4172, https://doi.org/10.1039/b817824k, 2009.

Witkowski, B. and Gierczak, T.: Characterization of the limonene oxidation products with liquid chromatography coupled to the tandem mass spectrometry, Atmos. Environ., 154, 297-307, https://doi.org/10.1016/j.atmosenv.2017.02.005, 2017.

Zhang, X., McVay, R. C., Huang, D. D., Dalleska, N. F., Aumont, B., Flagan, R. C., and Seinfeld, J. H.: Formation and evolution of molecular products in $\alpha$-pinene secondary organic aerosol., P. Natl. Acad. Sci. USA, 112, 14168-14173, https://doi.org/10.1073/pnas.1517742112, 2015.
Zhao, D. F., Kaminski, M., Schlag, P., Fuchs, H., Acir, I.-H., Bohn, B., Häseler, R., Kiendler-Scharr, A., Rohrer, F., Tillmann, R., Wang, M. J., Wegener, R., Wildt, J., Wahner, A., and Mentel, Th. F.: Secondary organic aerosol formation from hydroxyl radical oxidation and ozonolysis of monoterpenes, Atmos. Chem. Phys., 15, 991-1012, https://doi.org/10.5194/acp-15-991-2015, 2015.

Zhao, Y., Wingen, L. M., Perraud, V., Greaves, J., and FinlaysonPitts, B. J.: Role of the reaction of stabilized Criegee intermediates with peroxy radicals in particle formation and growth in air, Phys. Chem. Chem. Phys., 17, 12500-12514, https://doi.org/10.1039/C5CP01171J, 2015.

Zhao, Y., Wingen, L. M., Perraud, V., and Finlayson-Pitts, B. J.: Phase, composition, and growth mechanism for secondary organic aerosol from the ozonolysis of $\alpha$-cedrene, Atmos. Chem. Phys., 16, 3245-3264, https://doi.org/10.5194/acp-163245-2016, 2016.

Ziemann, P. J. and Atkinson, R.: Kinetics, products, and mechanisms of secondary organic aerosol formation, Chem. Soc. Rev., 41, 6582-6605, https://doi.org/10.1039/c2cs35122f, 2012.

Zuend, A., Marcolli, C., Luo, B. P., and Peter, T.: A thermodynamic model of mixed organic-inorganic aerosols to predict activity coefficients, Atmos. Chem. Phys., 8, 4559-4593, https://doi.org/10.5194/acp-8-4559-2008, 2008.

Zuend, A., Marcolli, C., Booth, A. M., Lienhard, D. M., Soonsin, V., Krieger, U. K., Topping, D. O., McFiggans, G., Peter, T., and Seinfeld, J. H.: New and extended parameterization of the thermodynamic model AIOMFAC: calculation of activity coefficients for organic-inorganic mixtures containing carboxyl, hydroxyl, carbonyl, ether, ester, alkenyl, alkyl, and aromatic functional groups, Atmos. Chem. Phys., 11, 9155-9206, https://doi.org/10.5194/acp-11-9155-2011, 2011. 